\title{
Big grains go far: understanding the discrepancy between tephrochronology and satellite infrared measurements of volcanic ash
}

\author{
J. A. Stevenson ${ }^{1}$, S. C. Millington ${ }^{2}$, F. M. Beckett ${ }^{2}$, G. T. Swindles ${ }^{3}$, and T. Thordarson ${ }^{4}$ \\ ${ }^{1}$ School of GeoSciences, University of Edinburgh, Edinburgh, UK \\ ${ }^{2}$ Met Office, Exeter, UK \\ ${ }^{3}$ School of Geography, University of Leeds, Leeds, UK \\ ${ }^{4}$ Institute of Earth Sciences, Háskóli Íslands, Reykjavík, Iceland
}

Correspondence to: J. A. Stevenson (johnalexanderstevenson@yahoo.co.uk)

Received: 31 October 2014 - Published in Atmos. Meas. Tech. Discuss.: 6 January 2015

Revised: 9 April 2015 - Accepted: 20 April 2015 - Published: 19 May 2015

\begin{abstract}
There is a large discrepancy between the size of volcanic ash particles measured on the ground at least $500 \mathrm{~km}$ from their source volcano (known as cryptotephra) and those reported by satellite remote sensing (effective radius of $0.5-9 \mu \mathrm{m} ; 95 \%$ of particles $<17 \mu \mathrm{m}$ diameter). Here we present new results from the fields of tephrochronology (a dating technique based on volcanic ash layers), dispersion modelling and satellite remote sensing in an attempt to understand why. A literature review and measurements of prehistoric and recent eruptions were used to characterise the size range of cryptotephra grains. Icelandic cryptotephra deposited in NW Europe has lognormal particle size distributions (PSDs) with median lengths of $20-70 \mu \mathrm{m}$ (geometric standard deviation: $1.40-1.66$; 95 th percentile length: $42-$ $126 \mu \mathrm{m})$. Grain-size range estimates from the literature are similar. We modelled the settling of volcanic ash using measured fall velocities of ash particles, a release height typical of moderate Icelandic eruptions $(10 \mathrm{~km})$, and a wind speed typical for NW Europe $\left(10 \mathrm{~m} \mathrm{~s}^{-1}\right)$, to show that an ash cloud can transport particles up to $80 \mu \mathrm{m}$ diameter up to $850 \mathrm{~km}$ in $24 \mathrm{~h}$. Thus, even moderately sized Icelandic eruptions can be expected to deposit cryptotephra on mainland Europe. Using simulated satellite infrared data for dispersion-modelderived ash clouds, we demonstrate a systematic bias towards small grain sizes in retrievals of volcanic ash clouds that contain large proportions of cryptotephra-sized grains. As the median radius of the simulated PSD increases, fewer ashcontaining pixels are correctly identified. Where retrievals are made of simulated clouds with mass median radii larger
\end{abstract}

than $\sim 10 \mu \mathrm{m}$, the mean retrieved $r_{\text {eff }}$ plateaus at around $9 \mu \mathrm{m}$. Assuming Mie scattering by dense spheres when interpreting satellite infrared brightness temperature difference (BTD) data puts an upper limit on retrieved particle sizes. If larger, irregularly shaped ash grains can also produce a BTD effect, this will result in further underestimation of grain size, e.g. in coarse ash clouds close to a volcano.

\section{Introduction}

Comparison between the fields of volcanology (tephrochronology), dispersion modelling and satellite remote sensing reveals striking differences in published distal volcanic ash grain-size data. Differences in their approaches and frame of reference are highlighted by the terminology of each. In volcanology, "coarse" ash refers to particles $1-2 \mathrm{~mm}$ in diameter and those $<64 \mu \mathrm{m}$ are classified as "extremely fine" (White and Houghton, 2006); in atmospheric science airborne particles coarser than $2 \mu \mathrm{m}$ diameter are defined as "coarse" aerosol (Seinfeld and Pandis, 2006). Furthermore, volcanologists describe particle sizes via grain lengths, whereas atmospheric scientists use the particle radius. Scientists who extract volcanic ash grains from soils or lakes hundreds of kilometres from their source typically report grain lengths of $20-125 \mu \mathrm{m}$ (Sect. 1.1). These tephra horizons are known as cryptotephra (hidden ashes) because they are found in deposits that are too thin 
and too low in concentration to be visible to the naked eye. In contrast, measurements of airborne volcanic ash clouds by satellite remote sensing and direct sampling by aircraft find particle size distributions (PSDs) with median radii of $1-4 \mu \mathrm{m}$ in which cryptotephra-sized grains form negligible proportions (Sect. 1.2). Assuming that the cryptotephra were transported to distal regions in volcanic ash clouds, their absence from measured ash cloud PSDs, particularly those close to the volcano (Sect. 1.3), is intriguing. This is the focus of this study, which integrates new results from all three disciplines to investigate the size distributions of distal cryptotephra deposits, volcanic ash transport models and the influence of larger particles on satellite infrared remote sensing results.

Our results highlight the importance of considering cryptotephra-sized grains in remote-sensing and atmospheric dispersion modelling and the need for empirical, quantitative measurements of the optical and aerodynamic properties of volcanic ash. They are presented in here in three sections: Sect. 2 covers cryptotephra size distributions, Sect. 3 covers transport models and Sect. 4 pertains to simulated satellite imagery. By presenting results from the three fields in a single paper we aim to improve understanding and communication between these diverse disciplines. In each section, particle sizes are described using the dimension appropriate to that field. These are length, diameter and radius, respectively. The findings are discussed in Sect. 5.

\subsection{Cryptotephra generation, transport and deposition}

There is abundant evidence for distal (> $500 \mathrm{~km}$ in the context of this study) volcanic ash transport provided by grains preserved in soil, peat and lake deposits, or in snow and glacial ice, which are identified by scientists researching these deposits (e.g. Persson, 1971; Dugmore, 1989; Abbott and Davies, 2012). Such distal deposits are too thin to form a visible layer, but ash grains can be extracted in the laboratory (Hall and Pilcher, 2002; Swindles et al., 2010). These "cryptotephra" grains (also called "microtephra" or glass "shards") are recognised by their glassy colour (with or without the presence of crystals), their highly irregular shapes and their often bubbly (vesicular) texture (Dugmore, 1989; Lowe, 2011; Jennings et al., 2014). Geochemical analyses by electron probe microanalysis (EPMA) or secondary ion mass spectrometry (SIMS) can link cryptotephra to their source volcano and possibly an eruption of known age, making tephrochronology a powerful dating tool (e.g. Swindles et al., 2010; Óladóttir et al., 2011; Hayward, 2012). The size of cryptotephra grains is described by their long axis length, defined as the longest distance between two parallel tangents across the grain. Cryptotephra grain sizes typically range from 20 to $>125 \mu \mathrm{m}$. These grains will have been the largest within the depositing cloud but, in reaching distal regions, they must have formed a significant proportion of the cloud closer to the volcano. Unfortunately, grain sizes are not routinely reported, and when they are the data are often just exemplar, modal or maximum lengths.

The initial PSD of volcanic ejecta leaving the vent of a volcano, collectively known as tephra, depends on the characteristics of the eruption that produced it. Particles can range in size over 7 orders of magnitude from microns to metres in diameter. The PSD of all ejected particles is known as the Total Deposit Grainsize Distribution (TGSD; Bonadonna and Houghton, 2005; Rust and Cashman, 2011). The TGSD varies significantly between eruptions and is strongly controlled by internal factors, such as the size distribution of bubbles in the magma or the gas content, and external factors such as particle collisions, ascent rate and interaction with water (Rose and Durant, 2009). Magma compositions typically range from basalt (high in $\mathrm{Mg}$ and $\mathrm{Fe}$, dark colour, $\rho_{\text {glass }}$ of $2.8-3.0 \mathrm{~g} \mathrm{~cm}^{-1}$ ) to rhyolite (high in $\mathrm{Si}$ and $\mathrm{Al}$, light colour, $\rho_{\text {glass }}$ of $2.4-2.6 \mathrm{~g} \mathrm{~cm}^{-1}$ ). Eruptions of rhyolite composition magma tend to produce volcanic ash grains that contain more, and smaller, bubbles than basaltic eruptions, so rhyolite ash is normally more abundant as well as less dense and slower settling than basalt ash. Interaction between magma and meltwater causes increased fragmentation, however, so subglacial basaltic eruptions can still produce extremely fine ash (e.g. $20 \mathrm{wt} \%$ of the Grímsvötn 2004 tephra was $<64 \mu \mathrm{m}$ in length; Jude-Eton et al., 2012). Cryptotephrasized grains make up a larger proportion of the ejected mass than the particles that are most easily identified in satellite infrared remote sensing data (less than $12 \mu \mathrm{m}$ diameter). Even in rhyolite eruptions, only around $1 / 3$ of ejected material is finer than $12 \mu \mathrm{m}$ diameter (Rust and Cashman, 2011).

The PSD evolves during transport as particles are deposited from the plume based on their terminal velocity. For bubbly and irregularly shaped volcanic ash particles this is typically $0.15-0.35 \mathrm{~m} \mathrm{~s}^{-1}$ (100 $\mu \mathrm{m}$ grains Riley et al., 2003), which is much less than a sphere of the same diameter. A $100 \mu \mathrm{m}$ grain may fall at the same rate as a sphere $9-50 \mu \mathrm{m}$ in diameter (Rose et al., 2003). The coarsest particles fall out quickly and PSDs of deposits show that particles $>500 \mu \mathrm{m}$ in length are mostly deposited within tens of kilometres of the volcano (Rose et al., 2001). In addition, a number of processes promote early deposition of cryptotephra-sized grains and, at distances up to $500 \mathrm{~km}$, deposits contain a significant proportion of ash particles $(<100 \mu \mathrm{m})$ that were deposited much earlier than would be predicted by single-particle settling velocities. Within the first tens of kilometres downwind, vertical gravity currents (similar to "microbursts") can transport particles to the ground faster than their individual terminal velocities as "streak fallout" (Eliasson et al., 2014). Aggregation and meteorological processes such as coating of ash particles by ice or water and subsidence of the entire volcanic plume may also be important in the distal evolution of the PSD (Durant et al., 2009). Satellite retrievals of ash cloud mass indicate that after $\sim 24 \mathrm{~h}$, just a small proportion $(<5 \%)$ of the erupted mass remains in the cloud to be transported to distal locations (Rose et al., 
2000, 2001; Gudmundsson et al., 2012). Comparisons of Numerical Atmospheric-dispersion Modelling Environment (NAME) dispersion model predictions with measurements from aircraft during the 2010 Eyjafjallajökull eruption found similar proportions (2-6\%; Dacre et al., 2013) .

\subsection{Satellite infrared detection of volcanic ash}

The wide spatial coverage of satellite remote sensing, combined with near-real time data for some methods, makes it a valuable tool for monitoring volcanic ash clouds. Different techniques use different parts of the electromagnetic spectrum. Visible and ultraviolet sensors detect scattered or reflected sunlight. Consequently, they can only be used during daytime. Ash clouds can be seen in satellite photographs (visible light), provided that they are not obscured by meteorological clouds, and ultraviolet spectrometers can be used to map sulfur dioxide, which is often transported alongside the volcanic ash (McCormick et al., 2013). Microwave (mmwavelength) radiation emitted by the Earth can be used to study volcanic ash clouds, during both night and day. Delene et al. (1996) adapted methods for calculating rainfall rates using satellite-based Special Sensor Microwave Imager (SSM/I) data to estimate the mass of ash fallout from volcanic clouds. As this method is sensitive to particles 0.1$1 \mathrm{~mm}$ in diameter that fall out quickly, it is limited to clouds up to a few hours old and close to the volcano. Microwave radiation is also used by ground-based weather radar systems that can retrieve the mass and size distribution of particles within a young volcanic plume within approximately $200 \mathrm{~km}$ of the equipment (Marzano et al., 2013; Montopoli et al., 2014). This is an active technique, using man-made radiation. Similarly, light detection and ranging (lidar) systems use lasers to measure the height and optical depth of ash clouds at a single location above a measuring station (Marenco and Hogan, 2011; Devenish et al., 2012). Depolarisation measurements can help distinguish irregularly shaped volcanic ash particles from other aerosol. The Cloud Aerosol LiDAR and Infrared Satellite Observations (CALIPSO) system makes space-based lidar observations of ash cloud altitude along a narrow track beneath its orbit (e.g. Prata and Prata, 2012), but cannot be used to map the lateral extent of clouds.

Here, we focus on satellite infrared measurements of volcanic ash. These are passive systems that use infrared energy radiated upwards from the Earth's surface, so they can be used in day or night. Geostationary satellites, e.g. Meteosat, provide wide coverage and data are updated in nearreal time (every $15 \mathrm{~min}$ for the Spinning Enhanced Visible and Infrared Imager instrument, SEVIRI), making them ideal for mapping ash clouds. Satellite infrared remote sensing distinguishes volcanic ash clouds from meteorological clouds using the different optical properties of ash and water or ice droplets (Prata, 1989; Wen and Rose, 1994). Infrared light is absorbed and scattered by ash, water and ice particles (as well as other aerosols) as it passes through the cloud and this affects the signal measured by a satellite instrument for a given pixel. The brightness temperature difference (BTD) of a pixel between two infrared channels centred at 10.8 and $12.0 \mu \mathrm{m}$ is often used to identify ash clouds (this is sometimes also referred to as the reverse-absorption or split-window method). Volcanic ash is more absorbing at $10.8 \mu \mathrm{m}$ than at $12.0 \mu \mathrm{m}$ and gives a negative BTD, whilst water vapour, water droplets and ice particles have the opposite characteristics. The BTD method has been used to identify volcanic ash for over two decades. It has some limitations. Clouds and water vapour in the atmosphere and the ash cloud, and temperature inversions above ice-covered land surfaces can also reduce the strength of the BTD effect (Prata et al., 2001; Kylling et al., 2013). Ash clouds with high concentrations are optically opaque, so have a BTD of zero (Rose et al., 2001). In a volcano monitoring setting, these clouds may still be recognised by skilled human operators but automatic detection using the BTD method is not possible. More sophisticated ash detection algorithms use extra tests to reduce false positives or negatives, or to take volcanic $\mathrm{SO}_{2}$ into account, by incorporating data from a third infrared channel (Francis et al., 2012; Pavolonis et al., 2013). Methods that take advantage of the many channels of hyperspectral data have also been developed (Gangale et al., 2010).

Once a pixel has been identified as ash contaminated, a retrieval can be made of ash cloud properties such as height, ash column loading and particle effective radius $\left(r_{\text {eff }}\right.$, which is a function of the PSD - see the Appendix; Wen and Rose, 1994; Prata and Prata, 2012; Francis et al., 2012; Pavolonis et al., 2013). Retrieval algorithms attempt to find the combination of parameters that best produce the observed brightness temperatures in a satellite image. By estimating the thickness of the ash cloud (e.g. $1 \mathrm{~km}$ ), the ash column loading (in $\mathrm{kg} \mathrm{m}^{-2}$ ) can be converted into a concentration (in $\mathrm{mg} \mathrm{km}{ }^{-3}$ ). These data have become more important since safety rules based on zones of different ash concentration were introduced during the 2010 Eyjafjallajökull eruption for aircraft flying in European airspace. Retrievals are based on the scattering of infrared light according to Mie theory. The strength of absorption and scattering by particles is a function of the wavelength, particle size, particle shape and the complex refractive indices of the volcanic glass from which it is formed (Pollack et al., 1973; Wen and Rose, 1994; Kylling et al., 2014). Mie scattering occurs when particles are of a similar size to the wavelength of the radiation, so the PSD is an important variable. Forward modelling based on Mie theory allows the absorption and scattering coefficients for a given $r_{\text {eff }}$, refractive index (ash composition) and wavelength to be predicted, usually based on the assumption that particles are dense spheres. Assuming a thin, homogeneous, semi-transparent, surface-parallel cloud, a radiative transfer model uses these coefficients to calculate the BTD for different PSDs (expressed in terms of their effective radius) and ash mass loading (a function of optical depth, $\tau_{\mathrm{c}}$ ) for 
Geometric standard deviation: 2.0
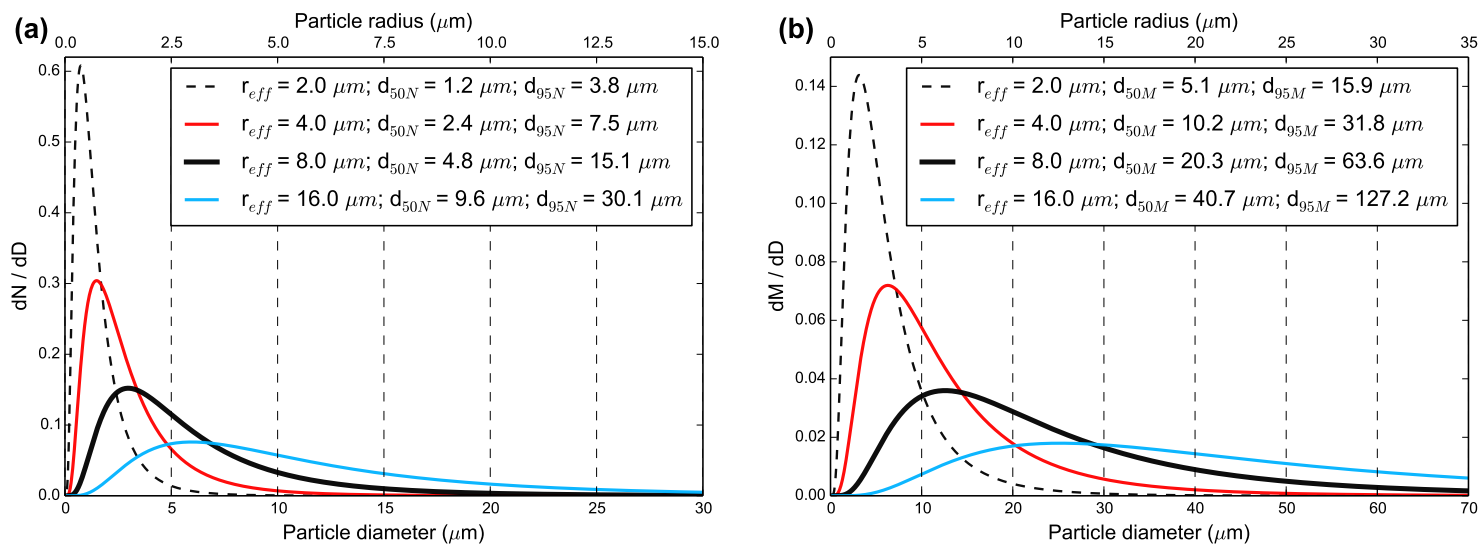

Figure 1. Lognormal number (a), and mass (b), grain-size distributions corresponding to different effective radii, assuming that particles are dense spheres. The mass distribution is shifted towards coarser values compared to the number distribution. The mass median diameter and mass 95th percentile diameter are approximately $2.5 \times$ and $8 \times r_{\text {eff }}$. For $r_{\text {eff }}>8 \mu \mathrm{m}$, more than half of the mass of the distribution is contained in cryptotephra-sized particles ( $>20 \mu \mathrm{m}$ diameter), but only distributions with larger $r_{\text {eff }}$ contain significant proportions of the coarsest cryptotephra-sized particles (i.e. $>100 \mu \mathrm{m}$ ). If the geometric standard deviation is less than 2.0, the size of the coarsest particles is much reduced.

a range of cloud heights and meteorological conditions (Wen and Rose, 1994). Some retrieval methods assume a fixed ash cloud altitude (Wen and Rose, 1994; Prata and Prata, 2012).

Each retrieved $r_{\text {eff }}$ represents a PSD containing a narrow range of particle sizes (see Fig. 1 for examples of different distributions and the Appendix for equations). It has been acknowledged since the BTD method was developed that it requires ash clouds dominated by particles $<10 \mu \mathrm{m}$ diameter, which corresponds to PSDs with an effective radius less than $\sim 17 \mu \mathrm{m}$ (Prata, 1989; Wen and Rose, 1994). Coarser particles should have no differential absorption effect and so should exhibit similar brightness temperatures at 10.8 and $12.0 \mu \mathrm{m}$. The implication of this, assuming that the BTD results from Mie scattering by dense spheres, is that it should not be possible to detect ash clouds close to their source, even if they are sufficiently dilute to be semi-transparent. At the limits of detection, a lognormal distribution with a geometric standard deviation, $\sigma$, of 2.0 and an effective radius of $17 \mu \mathrm{m}$ has $95 \%$ of particles $<32 \mu \mathrm{m}$ diameter, with $95 \%$ of the mass within particles $<135 \mu \mathrm{m}$. Such a distribution would contain cryptotephra-sized particles. Published values of retrieved $r_{\text {eff }}$, however, are never this high and range from 0.5 to $9 \mu \mathrm{m}$ (Grainger et al., 2013). These distributions have $95 \%$ of particles less than $0.9-17 \mu \mathrm{m}$ in diameter, respectively, with $95 \%$ of the mass within particles less than 4-72 $\mu \mathrm{m}$. These retrieved PSDs suggest that the proportion of cryptotephra-sized particles within ash clouds is small to negligible.

\subsection{Comparing remote sensing PSDs with proximal deposits}

In a few cases, satellite retrievals have been made of proximal $(<200 \mathrm{~km}$ in the context of this study) volcanic ash clouds where samples have also been taken from the ground. The PSDs of the deposits contain significant cryptotephrasized (and coarser) grains, yet the retrieved PSDs suggest that these formed a negligible proportion of the depositing ash cloud. For example, the deposits of the 1996 eruption of Ruapehu, New Zealand, are exceptionally well characterised (Bonadonna and Houghton, 2005). The total grainsize distribution of material deposited on land between 50 and $200 \mathrm{~km}$ from the volcano has a mode of $125 \mu \mathrm{m}$, with $>\sim 80 \%$ of deposited mass made up of grains coarser than $64 \mu \mathrm{m}$. This compares to effective radius estimates derived from AVHRR-2 and ATSR-2 data of 2-4 $\mu \mathrm{m}$ in the same region (Prata and Grant, 2001), which would imply that $95 \%$ of the mass is within grains with a diameter of less than 16$32 \mu \mathrm{m}$.

More recently, SEVIRI retrievals were compared with ground-based sampling during the 2010 Eyjafjallajökull summit eruption (Bonadonna et al., 2011). Samples collected on the ground $56 \mathrm{~km}$ downwind from the volcano on 6 May 2010 contained grains $1-500 \mu \mathrm{m}$ in diameter, with a mode of $64 \mu \mathrm{m}$ and were deposited at a sedimentation rate of $0.4 \times 10^{-4} \mathrm{~kg} \mathrm{~m}^{-2} \mathrm{~s}^{-1}$. The nearest available satellite retrieval for the same day was at a location $130 \mathrm{~km}$ downwind of the crater. The mean retrieved ash radius was $4 \mu \mathrm{m}$ corresponding to a sedimentation rate of $0.2-$ $0.4 \times 10^{-6} \mathrm{~kg} \mathrm{~m}^{-2} \mathrm{~s}^{-1}$, which is over 100 times less. It was suggested that the 2-orders-of-magnitude discrepancy over 
$50 \mathrm{~km}$ range is a "consequence of ash aggregation and convective instabilities".

Taking the Eyjafjallajökull 2010 summit eruption as a whole, Stohl et al. (2011) used SEVIRI data to inform the inversion of a Lagrangian particle dispersion model, and estimated that the total mass of ash of 2.8-28 $\mu \mathrm{m}$ diameter emitted over the entire duration of the eruption was $8.3 \pm 4.2 \mathrm{Tg}$. They included a secondary mode of coarser particles in the input size distribution (modal size $=180 \mu \mathrm{m}$ ) in order to match the measured size distributions on the ground. Their estimated erupted mass is nearly an order of magnitude lower than the $70 \mathrm{Tg}$ of particles finer than $28 \mu \mathrm{m}$ calculated by mapping the thickness, mass and grain-size distribution of tephra on the ground (Gudmundsson et al., 2012).

Comparing proximal deposits with satellite retrievals shows a large discrepancy in PSDs. Here we suggest that distal deposits are likely to have the same issue and suggest that it may result, in part, from the lack of sensitivity of the detection and retrieval methods to large particles and to the assumption of spherical particles used in the calculation of the extinction coefficients.

\section{Particle size distributions of cryptotephra}

\subsection{Method}

The size range of distal cryptotephra grains was constrained by a literature survey and by measurement of cryptotephra from a number of modern and ancient eruptions. Sample locations are listed in Table 2 and plotted on the map in Fig. 2. Cryptotephra from the 2010 Eyjafjallajökull and 2011 Grímsvötn eruptions were extracted from rainwater collected in northern Scotland, central England and Northern Ireland (Stevenson et al., 2013). Organic material was digested with $\mathrm{H}_{2} \mathrm{O}_{2}$ and the grains were concentrated by centrifuge. Ash from older eruptions (Hekla S, Hekla 4, Hekla 1104, Hekla 1158, Glen Garry) was sampled from peat bogs in Shetland (Scotland), northern England and Northern Ireland. Peat was ashed at $600{ }^{\circ} \mathrm{C}$ in a furnace, suspended in $10 \%$ $\mathrm{HCl}$ for $24 \mathrm{~h}$, and washed with deionised water. This removed the organic matter (Hall and Pilcher, 2002; Swindles et al., 2010). Ash grains from rainwater and peat samples were mounted on slides (using Naphrax and Histomount, respectively) and identified by examination under optical microscope at 400 times magnification on the basis of their colour, shape, bubble or crystal content and isotropic structure. Grain-size distributions were obtained by measuring the long axes of grains, using the graticule of the optical microscope. It is not possible to identify grains $<10-15 \mu \mathrm{m}$ long by this method, and some tephrochronology studies sieve samples and only examine grains $>20 \mu \mathrm{m}$. Around 100 grains were measured in each sample. The grain-size distribution of larger quantities of ash from the 1875 Askja eruption (collected from freshly fallen snow in Trysil, Norway), and the
Eyjafjallajökull 2010 eruption (extracted from rainwater in the Faroe Islands; Stevenson et al., 2012) was measured by laser diffraction using a Beckman Coulter Counter LS2000. These instruments measure $0.5 \mathrm{~g}$ of material and return the diameter of a sphere with an optically equivalent area to each particle for the size range $0.4-2000 \mu \mathrm{m}$. The equivalent area diameter is approximately $0.6-0.7$ times the long axis length (Riley et al., 2003).

The ancient cryptotephra was linked to specific eruptions based on their stratigraphic positions and their composition, as determined by EPMA analysis. This was carried out at the University of Edinburgh (Shetland Isles samples) and the University of Leeds (N. England samples). At Edinburgh, a CAMECA SX100 electron microprobe with an accelerating voltage of $15 \mathrm{kV}$, a beam current of $2 \mathrm{nA}$ and diameter of $5 \mu \mathrm{m}$ was used for the wavelength-dispersive spectroscopy (WDS) analyses. At Leeds a Jeol 8230 electron microprobe with an equivalent setup was used. Microprobes were calibrated using both natural and synthetic standards and instrument stability was monitored using a range of glass standards. Tephrabase (Newton et al., 2007) was used to identify the tephras.

\subsection{Results}

\subsubsection{Literature examples of cryptotephra grain sizes}

Literature data are summarised in Table 1 . They are dominated by single measurements of modal or maximum size. The work of Persson (1971) is a notable exception, and those data have been digitised and included here. Published sizes range from $10-150 \mu \mathrm{m}$, with values from $30-60 \mu \mathrm{m}$ being common.

The deposition of Icelandic cryptotephra in Europe is well characterised, with 19 cryptotephra from the past 1000 years identified to date (Swindles et al., 2011). Small eruptions such as Eyjafjallajökull 2010, Grímsvötn 2011 and Hekla 1510 deposited grains up to 110,80 and $70 \mu \mathrm{m}$ long respectively in the UK (800-1500 km from source; Stevenson et al., 2012, 2013; Dugmore et al., 1996). The most widespread layers (i.e. the Vedde ash) can be identified in Russia and Slovenia, over $2500 \mathrm{~km}$ from source (Lane et al., 2012). Some of the world's largest eruptions such as the Taupo Whakamaru eruption (New Zealand), the Toba Younger Toba Tuff eruption (Indonesia) and the Campanian Ignimbrite (Italy), deposited ash layers $2-10 \mathrm{~cm}$ thick containing significant quantities of grains $>64 \mu \mathrm{m}$ at distances of $>1000 \mathrm{~km}$ from their source (Matthews et al., 2012; Engwell et al., 2013). Such large eruptions, with Volcano Explosivity Index (VEI) scores of 7 or 8 , are rare (recurrence intervals of $>1000$ and > 10000 years, respectively; Newhall and Self, 1982). However, the correlation of the White River Ash (Alaska, $50 \mathrm{~km}^{3}$ tephra) with the AD860 tephra in Greenland and $\mathrm{Eu}-$ rope (7000 km range) shows that even eruptions of a size that 


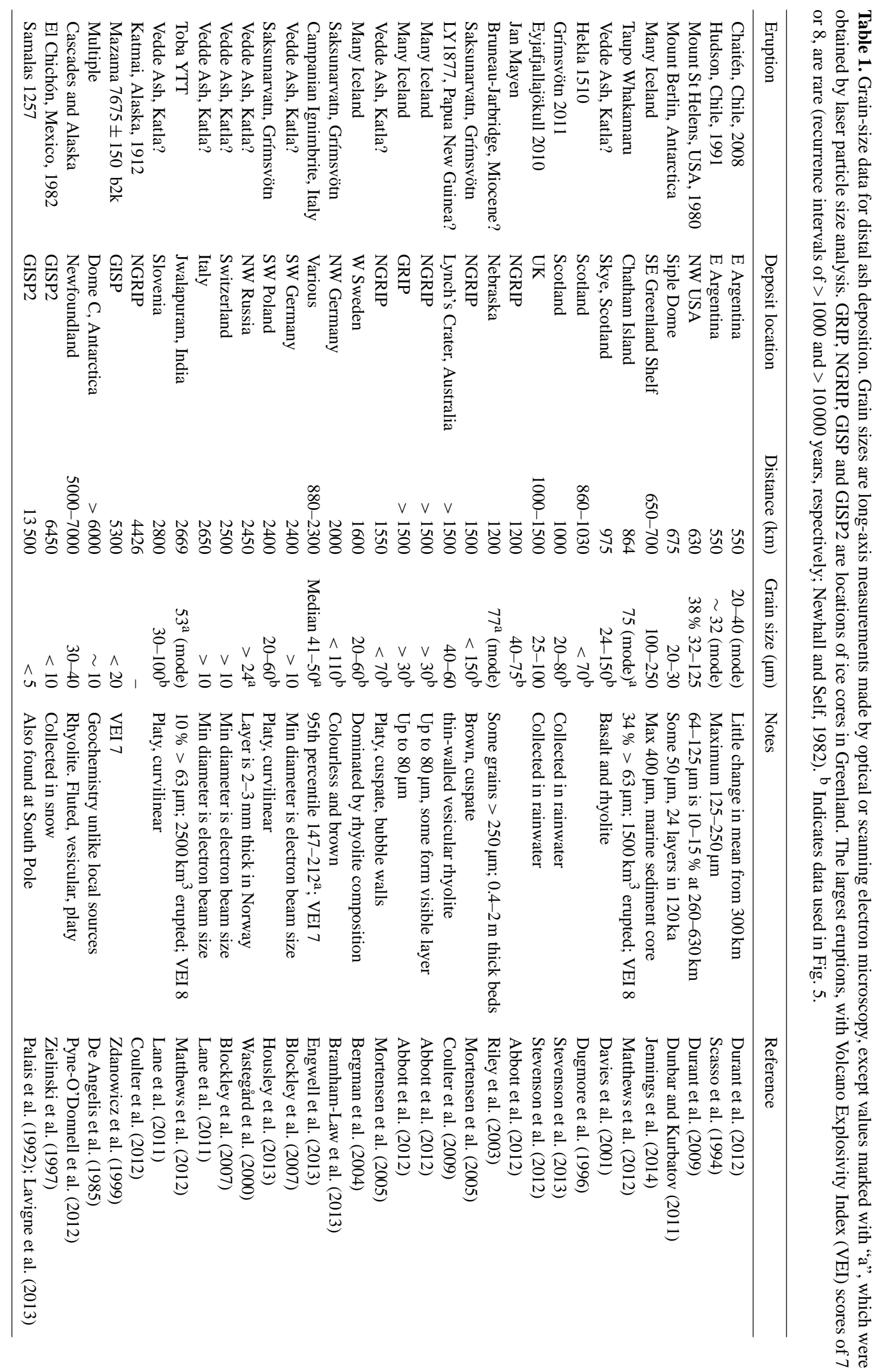



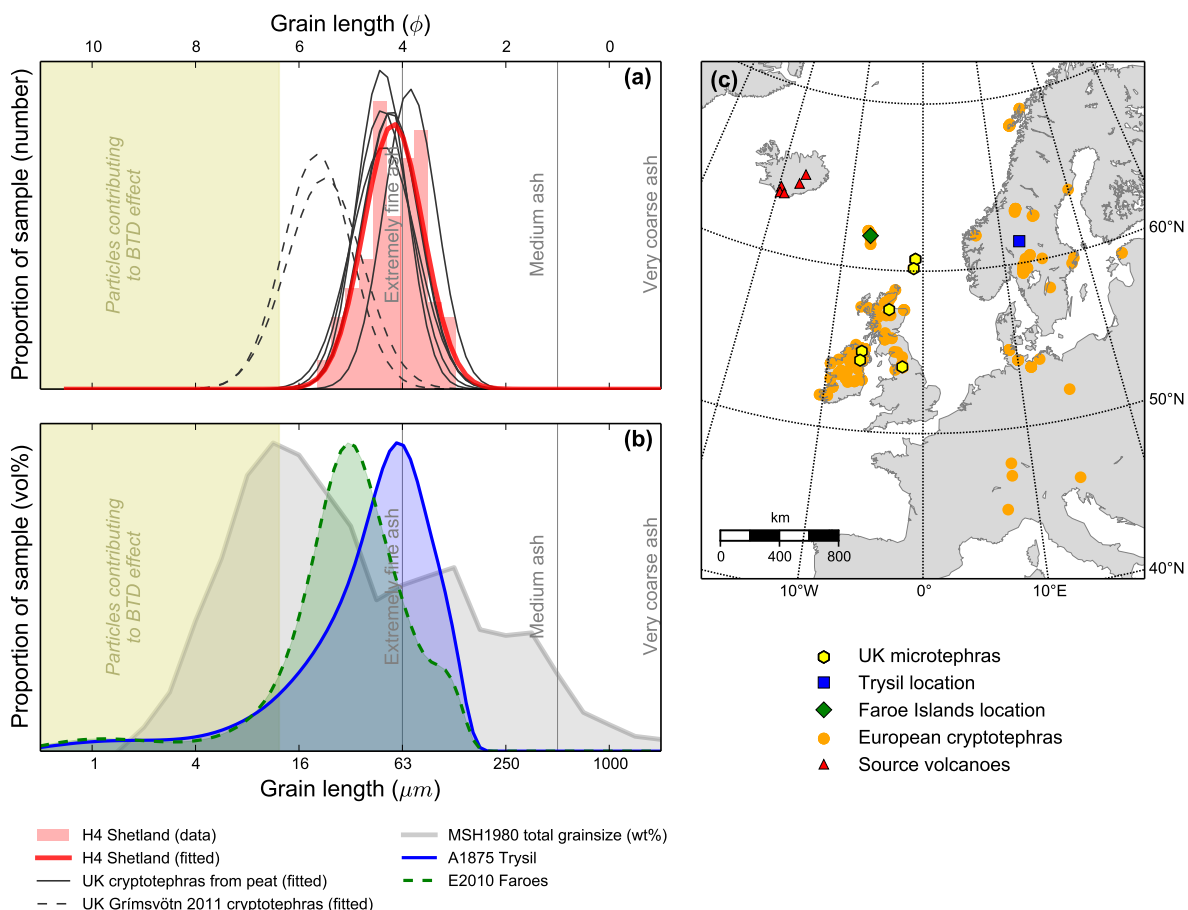

Figure 2. Deposition of Icelandic ash in Europe. (a) Long-axis number distributions of UK cryptotephra. The example histogram and red fitted curve represent the Hekla 4 eruption collected in Shetland, Scotland. The fitted curves (lognormal distribution) of UK cryptotephra extracted from peat or collected during the Grímsvötn 2011 eruption are also plotted. Grain sizes measured in $\phi$ units, where $\phi=-\log _{2}(d$ mm) are used in volcanology and sedimentology. (b) Particle size distributions measured by laser particle size analysis. Particles < $12 \mu \mathrm{m}$ are present only as a minor component and the modal grain sizes are similar to (a). The total deposit grain-size distribution of the $1980 \mathrm{Mount}$ St Helens eruption is plotted for comparison (Carey and Sigurdsson, 1982). (c) Map of sample locations and source volcanoes. Other European cryptotephra is plotted for context (Lawson et al., 2012; Lane et al., 2012; Bramham-Law et al., 2013; Housley et al., 2013). Limitations of identification methods imply that they have a minimum grain size of $\sim 20 \mu \mathrm{m}$.

occurs around once-per-century are capable of generating ultradistal cryptotephra (Jensen et al., 2014).

Ice cores provide an excellent record of distal cryptotephra as they are less contaminated by mineral grains and because peaks in sulfate concentration can be used to locate ash layers (Abbott and Davies, 2012), thus smaller grains $(<5 \mu \mathrm{m})$ from extremely distal events can also be identified. Ice core grain size and distance data are included in Table 1, and provide further evidence for transport of cryptotephra-sized grains to distances $>500 \mathrm{~km}$ from the source volcano. Icelandic volcanoes were the source of 37 of 45 cryptotephra identified in Greenland ice cores (Abbott and Davies, 2012). All layers, most of which were invisible to the naked eye, contained grains $>30 \mu \mathrm{m}$ and many had grains $>60 \mu \mathrm{m}$ length. The shortest distance from Iceland's most active volcanoes to the Greenland core sites is $\sim 1500 \mathrm{~km}$, but given the prevalence of westerly winds, it is likely that many of these arrived via a much longer, circumpolar route (Mortensen et al., 2005). Cryptotephra grains from volcanoes in the USA (Mount Mazama, Aniakchak, Katmai) and Mexico (El Chichón) are also found. In Antarctica, ice cores (e.g. Dome C, Siple Dome) also yield ash grains; those with different chemistry to local sources (e.g. Antarctic volcanoes, Deception Island,
Taupo) are attributed to much more distant $(6000 \mathrm{~km})$ eruptions (i.e. Andean volcanoes; De Angelis et al., 1985). In the case of the 1257 eruption of Samalas volcano, Indonesia (Lavigne et al., 2013), tephra shards $<5 \mu \mathrm{m}$ long with matching compositions have been found at both the GISP2 site in Greenland and the South Pole site in Antarctica (Palais et al., 1992), implying a transportation range of $13500 \mathrm{~km}$.

\subsubsection{Measured grain-size distributions of Icelandic cryptotephra}

Grain-size distribution curves are compared in Fig. 2a, while the measured data and fitted curves are shown in Fig. 3 and in the Supplement. Their statistics are summarised in Table 2. The PSDs for the cryptotephra recovered from peat and measured by counting via optical microscope are best described $\left(r^{2}>98 \%\right)$ by lognormal distributions with number median lengths of $48-70 \mu \mathrm{m}$ and geometric standard deviations $(\sigma)$ of 1.40-1.55, corresponding to $95 \%$ of particles less than $42-126 \mu \mathrm{m}$ long. The PSDs of Grímsvötn 2011 cryptotephra were finer (median lengths 19-23 $\mu \mathrm{m}$ ). Lognormal distributions have a skewed shape compared to normal distributions and have a coarse tail. Reporting the arithmetic mean and 

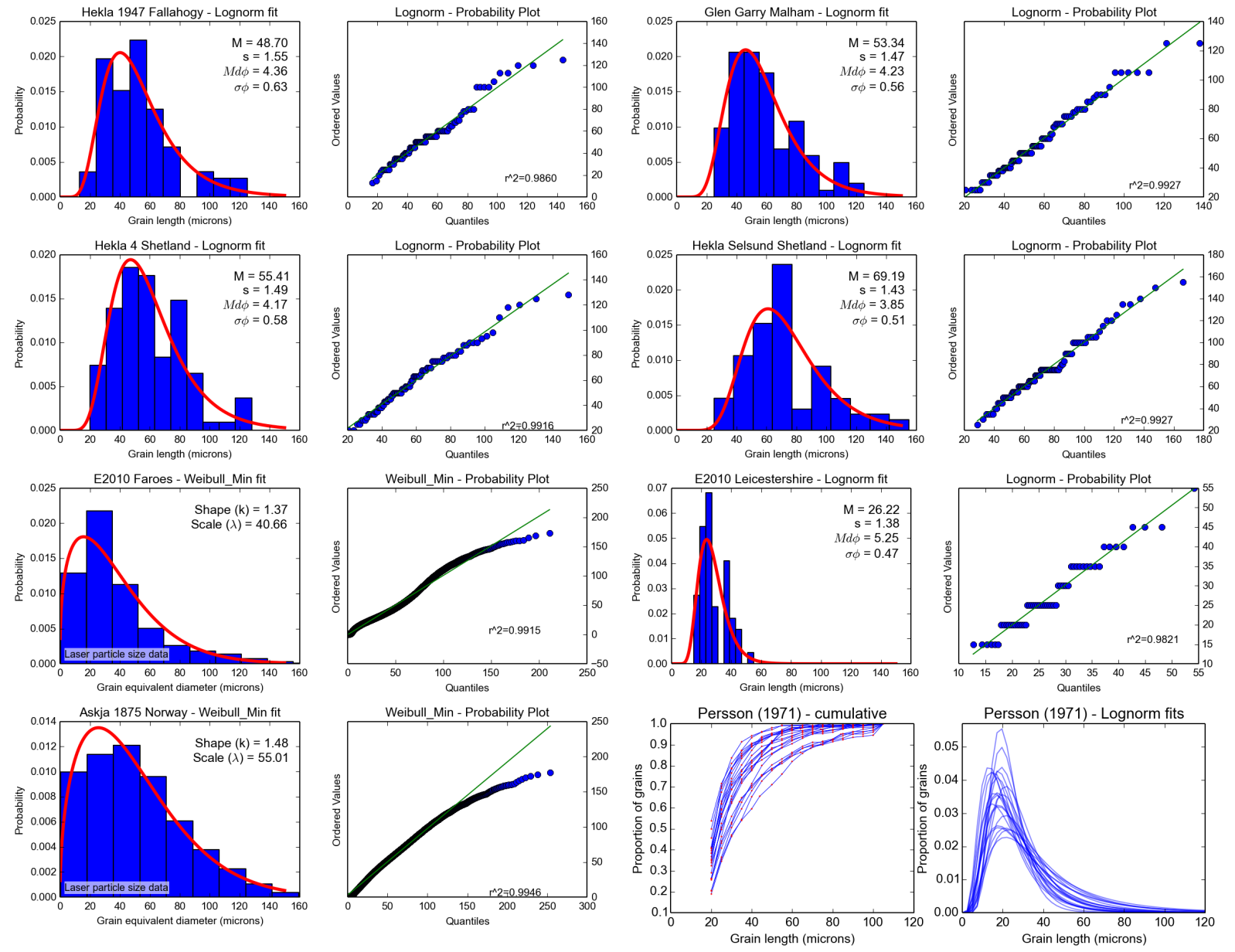

Figure 3. Statistical model fits to distal tephra grain-size distributions. Optical microscope cryptotephra lengths are well characterised by a lognormal distribution. Coulter counter data (Askja 1875 Norway, Eyjafjallajökull 2010 Faroes), which have a fine tail, are better fit by Weibull distributions. Data from Persson (1971) are shown for comparison. See Supplement for additional examples.

standard deviation of lognormally distributed data, as is often done in tephrochronology literature, underestimates the relative proportion of fine grains as well as the maximum likely grain size. The distributions are narrower than those obtained through airborne sampling of distal ash clouds $(\sigma=1.8-2.5$; Johnson et al., 2012) and contain a negligible proportion $(\ll 1 \%)$ of grains $<12 \mu \mathrm{m}$ long that would produce a BTD effect. The particles are vesicular and extremely irregular in shape (Fig. 4), as is typical for cryptotephra. Their optical properties and fall velocities are therefore unlike those of dense spheres.

The cryptotephra size distributions presented here are number distributions in terms of grain length. Due to the vesicular and extremely irregular shape of the grains, it is not appropriate to assume that they are dense spheres when converting to a mass distribution. One possible approach is to convert the median grain lengths into median equivalent volume diameters using the ratios calculated by Riley et al. (2003) for different compositions. These range from 1.05-
1.17 for basalt and 1.14-1.33 for rhyolite. Results of this are shown in Table 3. Without specific information on particle shape and vesicularity, it is not possible to determine the correct ratio, and these numbers are reported solely to illustrate that the bulk of the mass of the size distribution is within the larger particles.

Samples from the Askja 1875 and Eyjafjallajökull 2010 eruptions collected in Norway and the Faroe Islands, respectively, contained sufficient material for Coulter Counter laser diffraction particle size analysis. Their PSDs (Fig. 2b) are best described by Weibull distributions, with a shape of $1.37-1.48$ and a scale of $40-55 \mu \mathrm{m}$. This form of PSD has been linked to the sequential fragmentation/transport model of tephra grain-size evolution (Wohletz et al., 1989) and may be typical of laser diffraction data. Distal Campanian Ignimbrite deposits measured in a similar fashion are also well described by Weibull distributions (shape $0.95-1.22$, scale: 58-72; Engwell et al., 2013). The Weibull distribution has a fine tail compared to the lognormal distribution and contains 
Table 2. Grain-size distribution parameters for distal cryptotephra. $D_{50 \mathrm{~N}}$ is the median number diameter ( $\left.\mu \mathrm{m}\right), \sigma$ is the geometric standard deviation of the lognormal number distribution of grain length, except for two Eyjafjallajökull 2010 and Askja 1875 laser particle sizer examples, which are better fitted by a Weibull distribution, whose parameters are given in this case (italics). $95 \%$ of the particles have length of less than $D_{95 \mathrm{~N}}(\mu \mathrm{m})$. Data from Persson (1971) are also summarised.

\begin{tabular}{|c|c|c|c|c|c|c|c|}
\hline Eruption & Location & Coordinates & Distance (km) & Method & $D_{50 \mathrm{~N}}$ & $\sigma$ & $D_{95 \mathrm{~N}}$ \\
\hline Hekla 4 & Shetland & $-0.93^{\circ} \mathrm{E}, 60.72^{\circ} \mathrm{N}$ & 1050 & Microscope & 55.41 & 1.49 & 106.8 \\
\hline Hekla 4 & Malham & $-2.17^{\circ} \mathrm{E}, 50.10^{\circ} \mathrm{N}$ & 1050 & Microscope & 47.89 & 1.46 & 89.2 \\
\hline Hekla Selsund & Shetland & $-0.93^{\circ} \mathrm{E}, 60.72^{\circ} \mathrm{N}$ & 1050 & Microscope & 69.19 & 1.43 & 124.6 \\
\hline Hekla 1104 & Shetland & $-0.93^{\circ} \mathrm{E}, 60.72^{\circ} \mathrm{N}$ & 1050 & Microscope & 54.09 & 1.47 & 101.9 \\
\hline Hekla 1158 & Shetland & $-0.93^{\circ} \mathrm{E}, 60.72^{\circ} \mathrm{N}$ & 1050 & Microscope & 47.49 & 1.40 & 82.6 \\
\hline Hekla 1947 & Fallahogy & $-6.56^{\circ} \mathrm{E}, 54.91^{\circ} \mathrm{N}$ & 1250 & Microscope & 48.70 & 1.55 & 100.1 \\
\hline Glen Garry & Malham & $-2.17^{\circ} \mathrm{E}, 54.10^{\circ} \mathrm{N}$ & 1450 & Microscope & 53.34 & 1.47 & 100.5 \\
\hline Grímsvötn 2011 & Armagh & $-6.65^{\circ} \mathrm{E}, 54.35^{\circ} \mathrm{N}$ & 1250 & Microscope & 22.09 & 1.66 & 50.8 \\
\hline Grímsvötn 2011 & Auldearn 23 May & $-3.87^{\circ} \mathrm{E}, 57.59^{\circ} \mathrm{N}$ & 980 & Microscope & 22.82 & 1.57 & 47.9 \\
\hline Grímsvötn 2011 & Auldearn 24 May & $-3.87^{\circ} \mathrm{E}, 57.59^{\circ} \mathrm{N}$ & 1050 & Microscope & 22.57 & 1.56 & 46.9 \\
\hline Grímsvötn 2011 & Lerwick & $-1.14^{\circ} \mathrm{E}, 60.15^{\circ} \mathrm{N}$ & 960 & Microscope & 19.92 & 1.58 & 42.3 \\
\hline Eyjafjallajökull 2010 & Aberdeen & $-2.10^{\circ} \mathrm{E}, 57.15^{\circ} \mathrm{N}$ & 1200 & Microscope & 29.9 & 1.63 & 67.0 \\
\hline Eyjafjallajökull 2010 & Benbecula & $-7.34^{\circ} \mathrm{E}, 57.43^{\circ} \mathrm{N}$ & 955 & Microscope & 17.1 & 1.39 & 29.4 \\
\hline Eyjafjallajökull 2010 & Leicestershire & $-1.29^{\circ} \mathrm{E}, 52.73^{\circ} \mathrm{N}$ & 1610 & Microscope & 26.2 & 1.38 & 44.7 \\
\hline Persson (various) & Scandinavia & Various & $650-1840$ & Microscope & $19-33$ & $1.43-1.98$ & $45-100$ \\
\hline Eyjafjallajökull 2010 & Faroe Islands & $-6.79^{\circ} \mathrm{E}, 62.01^{\circ} \mathrm{N}$ & 675 & Coulter & $40.66^{1}$ & $1.37^{2}$ & 90.6 \\
\hline Askja 1875 & Trysil, Norway & $12.25^{\circ} \mathrm{E}, 61.33^{\circ} \mathrm{N}$ & 1500 & Coulter & $55.01^{1}$ & $1.48^{2}$ & 115.5 \\
\hline
\end{tabular}

${ }^{1}$ Weibull scale; ${ }^{2}$ Weibull shape.

particles $<12 \mu \mathrm{m}$ that would be missed by the microscope counting method. However, Fig. 2 shows that these particles represent only a small proportion of grains and that the microscope counting method correctly captures the peak of the cryptotephra size distribution. The Mount St Helens 1980 TGSD data also plotted in Fig. 2 illustrate the wide range of particle sizes released at the vent during explosive eruptions.

Figure 5 shows the variation in grain size of Icelandic cryptotephra in Europe with distance from the source volcano. There is significant scatter in the tephrochronological data, which represents particles from different eruptions with different meteorological conditions. Few cryptotephra are finer than $20 \mu \mathrm{m}$, although part of this is due to limitations in identifying smaller grains. Most are less than $60 \mu \mathrm{m}$ long. There is very poor correlation between diameter and transport distance. The UK-deposited cryptotephra from the 2011 Grímsvötn eruption are notable for their small grain size. Stevenson et al. (2013) showed that these were transported from the lowest $4 \mathrm{~km}$ of the eruption plume, which may explain their small size. With the exception of Hekla 1947, UK cryptotephra from Hekla are rhyolite in composition and are characterised by relatively large grain sizes (95th percentile grain diameters of $82-125 \mu \mathrm{m}$ ). The coarsest distal examples from the literature correspond to the Saksunarvatn and Vedde Ash tephras, whose grains are characterised by bubble-wall shaped shards of thin volcanic glass (Lane et al., 2011; Housley et al., 2013).

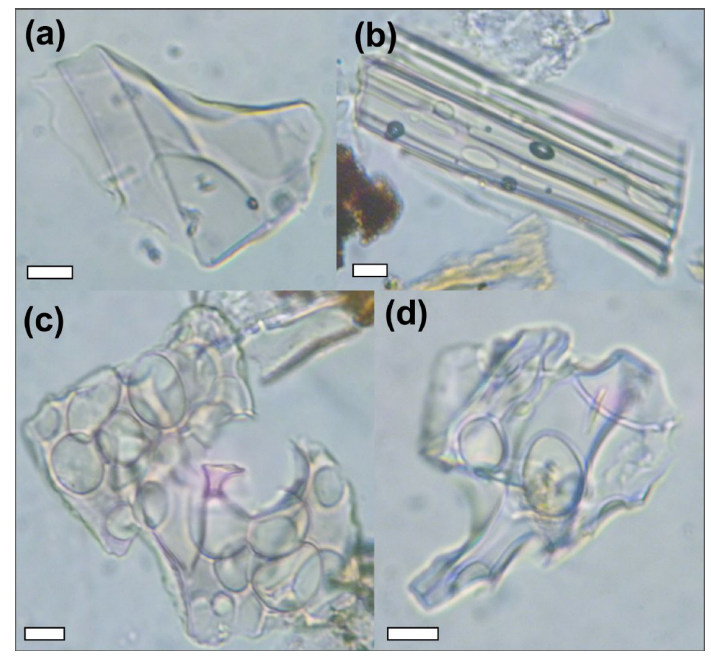

Figure 4. Light microscope images illustrating tephra shards found in Europe: (a and d) Glen Garry tephra, N. England; (b and c) Hekla-Selsund tephra, Shetland Isles. The tephra shards have different morphological characteristics: (a) platy; (b) pulled; (c) bubbly; (d) bubbly and platy. Their optical and aerodynamic properties are unlike dense spheres. Scale bars are $10 \mu \mathrm{m}$ in length. 
Table 3. Estimated grain-size mass distribution parameters for distal cryptotephra using data from Table 2 and extreme examples of ratios of particle length to particle spherical equivalent diameter from Riley et al. (2003). $D_{50 \mathrm{M}}$ is the median mass diameter ( $\left.\mu \mathrm{m}\right)$; $95 \%$ of the mass is within particles with diameters less than $D_{95 \mathrm{M}}(\mu \mathrm{m})$.

\begin{tabular}{llrrrrr}
\hline \multirow{2}{*}{ Eruption } & Location & \multicolumn{2}{c}{ Basalt } & $(1.05)$ & & \multicolumn{2}{c}{ Rhyolite $(1.33)$} \\
\cline { 7 - 8 } & & $D_{50 \mathrm{M}}$ & $D_{95 \mathrm{M}}$ & & $D_{50 \mathrm{M}}$ & $D_{95 \mathrm{M}}$ \\
\hline Hekla 4 & Shetland & 85.03 & 163.85 & & 67.13 & 129.36 \\
Hekla 4 & Malham & 70.09 & 130.61 & & 55.33 & 103.11 \\
Hekla Selsund & Shetland & 96.72 & 174.20 & & 76.36 & 137.52 \\
Glen Garry & Malham & 79.30 & 149.44 & & 62.60 & 117.98 \\
Hekla 1104 & Shetland & 80.41 & 151.54 & & 63.48 & 119.64 \\
Hekla 1158 & Shetland & 63.52 & 110.48 & & 50.15 & 87.22 \\
Hekla 1947 & Fallahogy & 82.52 & 169.69 & & 65.15 & 133.96 \\
Grímsvötn 2011 & Armagh & 45.46 & 104.64 & & 35.89 & 82.61 \\
Grímsvötn 2011 & Auldearn 23 May & 40.02 & 84.03 & & 31.59 & 66.34 \\
Grímsvötn 2011 & Auldearn 24 May & 38.90 & 80.84 & & 30.71 & 63.82 \\
Grímsvötn 2011 & Lerwick & 35.54 & 75.42 & & 28.06 & 59.54 \\
\hline
\end{tabular}

\section{Model constraints on cryptotephra transport}

\subsection{Method}

We carried out simple transport modelling to determine the terminal velocity and transport range of cryptotephra particles, which depend on the size, density and shape of the particle, and on atmospheric conditions (including the wind velocity) and the release height. The aim was to investigate the size of ash grains capable of being deposited in Europe following a moderately sized Icelandic eruption. We used two different schemes to calculate particle terminal fall velocity. The simplest possible scheme uses Stokes' settling law and assumes spherical particles with a density of $2300 \mathrm{~kg} \mathrm{~m}^{-3}$ (rhyolitic glass) falling in a constant atmosphere. A more realistic analysis accounts for the non-spherical shape of the particles by using a Reynolds number dependent drag coefficient (Ganser, 1993) that varies with the sphericity $\left(\Psi_{R}\right)$ of the particle (see Appendix B for details). $\Psi_{R}=0.7$ was chosen for the Ganser scheme based on values from Riley et al. (2003) for a rhyolitic composition (Ash Hollow member, Nebraska; $\Psi_{R}=0.6-0.8$ ). The variation in density with grain size was incorporated by using the relationship presented by Bonadonna and Phillips (2003), where the density decreases linearly from that of dense glass $\left(2300 \mathrm{~kg} \mathrm{~m}^{-3}\right.$ for Askja 1875) to that of pumice $\left(440 \mathrm{~kg} \mathrm{~m}^{-3}\right)$ as size increases from 8 to $2000 \mu \mathrm{m}$.

The more realistic analysis also uses a standard, stratified, atmosphere where the atmospheric density and viscosity decrease upwards, causing the terminal velocity of the ash particles to increase with height above sea level. The atmospheric effect is minor compared to corrections for the sphericity and density distribution of the ash particles, which act to decrease settling velocity.

The two schemes were compared to measured terminal fall velocities (at sea level) of ash particles given by Riley

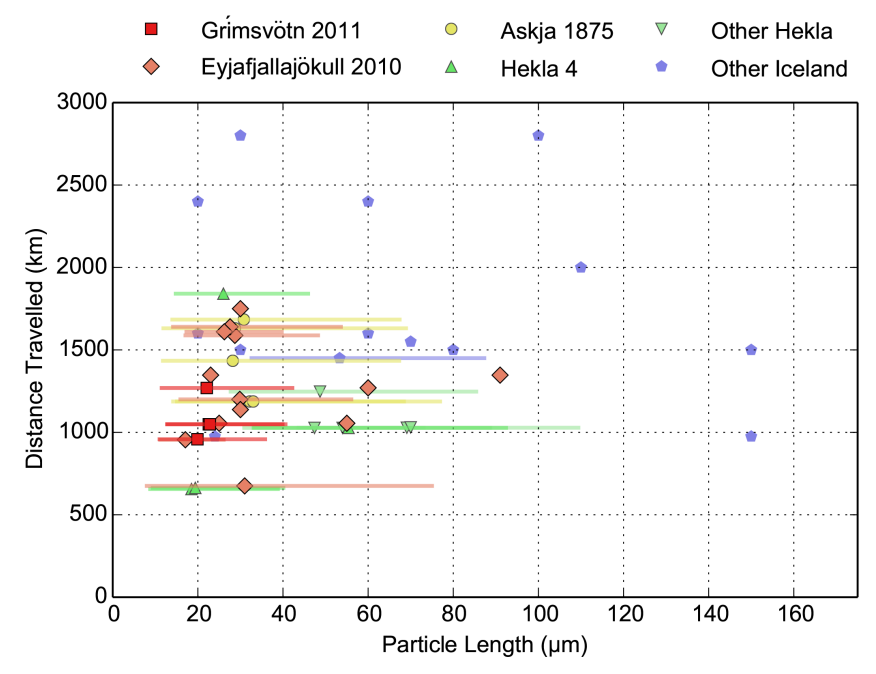

Figure 5. Diameter and travel distance of Icelandic cryptotephra in Europe. Both examples from the literature (Table 1) and those measured for this study (Table 2) are plotted. Horizontal coloured bars extend from the 10th to the 90th percentiles of the PSDs.

et al. (2003), who report data for basaltic, andesitic and rhyolite compositions as a function of dimensions such as longaxis length and equivalent area diameter (Fig. 6). These dimensions correspond to the microscope measurements made by tephrochronologists and to optical particle size measuring equipment, respectively (Sect. 2.1).

A mean wind speed of $10 \mathrm{~m} \mathrm{~s}^{-1}$ was chosen based on NCEP re-analysis data of wind speeds over Iceland during the eruption of Eyjafjallajökull in spring 2010 (Petersen et al., 2012) and timings of contemporary reports of volcanic ash pollution in Europe following Icelandic eruptions (Askja 1875, Hekla 1947, Eyjafjallajökull 2010, Grímsvötn 2011; see Table 4). We used a release height of $10 \mathrm{~km}$, the max- 


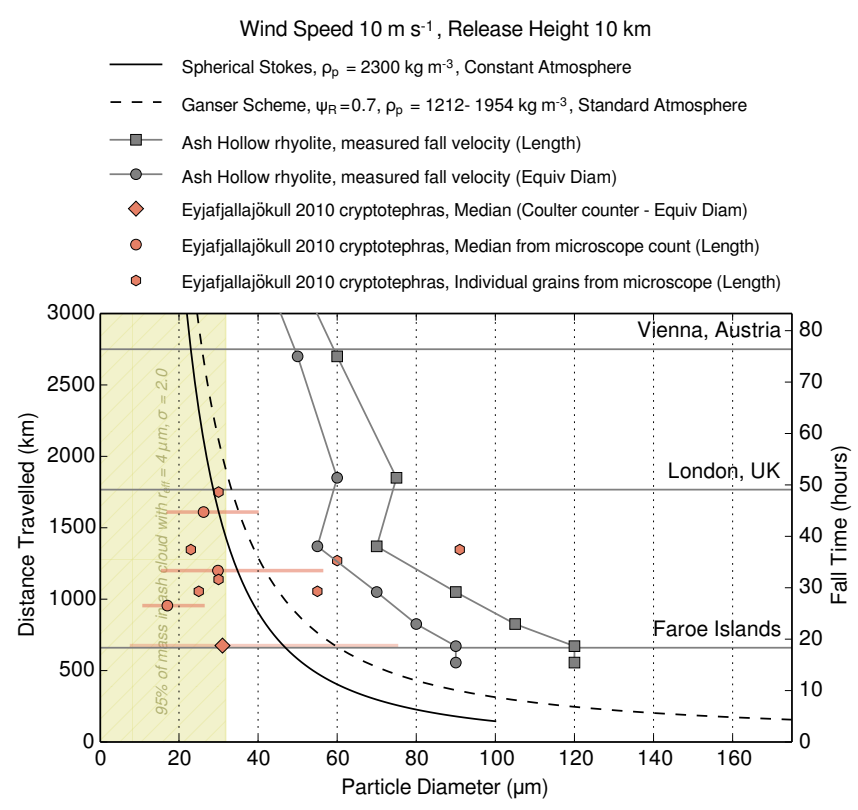

Figure 6. Modelled travel distance of ash particles as a function of particle diameter. The grey horizontal lines represent the distances from Eyjafjallajökull to various European locations. Measured particle sizes from the Eyjafjallajökull 2010 eruption are plotted for comparison. Horizontal coloured bars extend from the 10th to the 90th percentiles of the PSDs. The shaded region indicates the 95th percentile size range implied by an $r_{\mathrm{eff}}$ of $4 \mu \mathrm{m}$ and $\sigma$ of 2.0 .

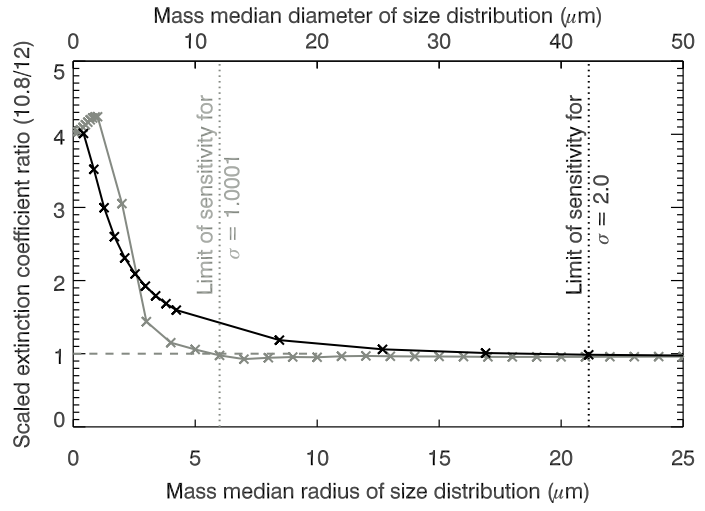

Figure 7. Scaled extinction coefficient ratio for SEVIRI channels at 10.8 and $12.0 \mu \mathrm{m}$ for spherical andesite volcanic ash particles as a function of ash particle size. The dotted line shows the grain size at which the reverse absorption technique becomes insensitive to andesite volcanic ash. It is not possible to use BTD effects to identify or automatically detect uniformly sized spherical andesite particles with radius $>6 \mu \mathrm{m}$. With a geometric standard deviation of 2.0, the BTD effect extends to mass median radius of $21 \mu \mathrm{m}$ (black line). This corresponds to an effective radius of $16.5 \mu \mathrm{m}$, which is comparable to the findings of Wen and Rose (1994). The sensitivity decreases rapidly with increasing mass median radius, particularly below the single-particle detection limit of $6 \mu \mathrm{m}$.
응응

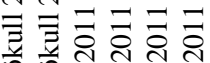


Table 5. Summary of transport model results. Ash Hollow results are based on particles of rhyolite composition.

\begin{tabular}{lrr}
\hline Scheme & $\begin{array}{r}\text { Maximum } \\
\text { diameter } \\
\text { airborne for } \\
24 \mathrm{~h}(\mu \mathrm{m})\end{array}$ & $\begin{array}{r}\text { Maximum } \\
\text { diameter reaching } \\
\text { London } \\
(\mu \mathrm{m})\end{array}$ \\
\hline Stokes & 41 & 29 \\
Ganser & 50 & 33 \\
Ash Hollow (equiv. diam) & 80 & 60 \\
Ash Hollow (length) & $115-135$ & $85-105$ \\
\hline
\end{tabular}

imum plume height of the 2010 Eyjafjallajökull eruption, which is reasonable for a moderately sized Icelandic eruption (Gudmundsson et al., 2012). Atmospheric turbulence, rising or subsiding air masses and particle aggregation are neglected in these simple treatments.

\subsection{Results}

Given a horizontal wind speed of $10 \mathrm{~m} \mathrm{~s}^{-1}$, particles can be transported $850 \mathrm{~km}$ in $24 \mathrm{~h}$. This is consistent with results of detailed climatological analysis that found that ash from a small Hekla eruption has a $15 \%$ probability of reaching Scotland, Northern Ireland, Norway or Sweden within 24 h, but that transport as far as the Mediterranean was also possible in that time (Leadbetter and Hort, 2011). The formation of cryptotephra deposits also depends on how long the particles remain airborne. This was calculated using each of the particle terminal velocity schemes, along with the distance travelled in that time. The results are shown in Fig. 6 and summarised in Table 5.

All schemes predict that cryptotephra-sized particles released by a moderately sized Icelandic eruption can remain airborne for at least $24 \mathrm{~h}$ and can travel as far as the distance to London under reasonable wind conditions. The Stokes and Ganser schemes give similar results, with the Ganser scheme predicting that particles can travel slightly further. Using the Riley et al. terminal velocity data for Ash Hollow rhyolite particles results in a significant increase in the predicted travel distance of ash particles compared to the Stokes and Ganser schemes. It corresponds to a 3 times increase over dense spheres for $50 \mu \mathrm{m}$ equivalent area diameter particles (Fig. 6). Ash Hollow data are presented both in terms of particle length and particle equivalent area diameter. For rhyolite, the particle length is $1.44-1.71$ times the equivalent area diameter of the same particle (Riley et al., 2003). The measured terminal velocity of rhyolite particles was lower than basaltic particles, which fell at the same rate as rhyolite particles 1.18-1.68 times their equivalent area diameter. The uncertainties on measured Ash Hollow particle lengths for given terminal velocities are not known but are likely to be significant.

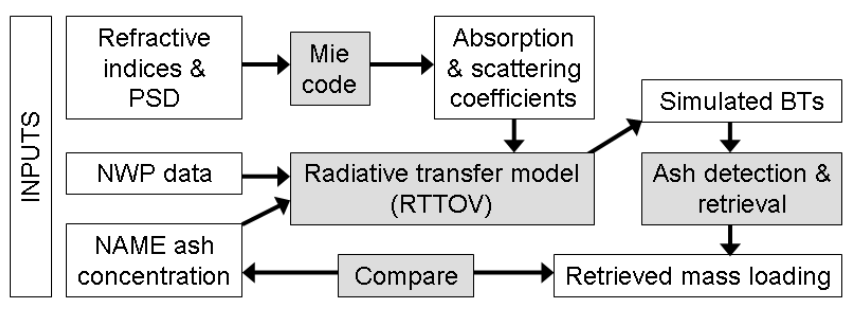

Figure 8. Schematic of the method used to compare input ash mass concentration and retrieved ash mass loading. The white boxes contain data and the grey boxes represent code.

These results show that in the absence of processes such as rainfall or aggregation, we should expect even moderately sized Icelandic eruptions to deposit cryptotephra in mainland Europe. The calculated transport distances of particles are compatible with our cryptotephra grain-size distributions and with measurements of maximum grain size by tephrochronologists (Fig. 6). Median cryptotephra transport distances from our results are generally well represented by the calculated distances using the Stokes or Ganser schemes, but calculations based on measured Ash Hollow fall velocities are closer to maximum grain-size measurements and the coarsest literature values.

\section{Satellite infrared retrievals of cryptotephra-rich plumes}

\subsection{Method}

We investigated how satellite infrared retrievals of ash characteristics change as the particle size increases. We used a modelling approach based on simulated satellite imagery representing data from the Spinning Enhanced Visible and Infrared Imager (SEVIRI) instrument on the geostationary Meteosat satellite (Millington et al., 2012; Kylling et al., 2013). Consequently, the input parameters were known and could be controlled. As the assumptions used in generating the simulated images are the same as those used in the retrievals, this represents a validation of the retrieval algorithm itself and not the physics of the BTD technique. Mie theory was used to model the absorption and scattering coefficients, which were combined to form a scaled extinction coefficient for volcanic ash with different refractive indices and size distributions at different wavelengths of infrared. This quantifies the sensitivity of the BTD effect to particle composition and size. It is an approximation for the effects of multiple scattering and therefore a better indication of the extinction properties than the single-scattering extinction coefficient. The refractive indices for andesite (Pollack et al., 1973) were used, in common with other studies (e.g. Pavolonis et al., 2006; Francis et al., 2012). Millington et al. (2012) quantified the effect of using the refractive indices of andesite, volcanic dust, obsidian and desert dust to simulate 
images of volcanic ash clouds. They found that data simulated using andesite and desert dust refractive indices gave the best agreement with measured satellite data for the 2010 Eyjafjallajökull eruption and the effect of varying refractive index on the simulated BTD was much smaller than that of changing the concentration or particle size distribution. For single particles, the geometric standard deviation $(\sigma)$ was set to 1.0001 to effectively create an infinitely narrow distribution where all the particles are a single size, and the mass median radius $\left(r_{\mathrm{m}}\right)$ of the size distribution was varied from 0.1 to $25 \mu \mathrm{m}$. To simulate an ash cloud with a range of sizes, the $\sigma$ was set to 2.0, similar to Pavolonis et al. (2013).

Radiative transfer calculations were performed using RTTOV-11, which is a very fast radiative transfer model for nadir viewing passive infrared and microwave satellite radiometers, spectrometers and interferometers (see Matricardi, 2005; Saunders et al., 2012, for details of the RTTOV-11 aerosol scattering and absorption scheme and validation data). The inputs to RTTOV-11 were Numerical Atmospheric-dispersion Modelling Environment (NAME; Jones et al., 2006) simulations of a volcanic ash cloud and Numerical Prediction Weather (NWP) meteorological data from the Met Office's Global version of the Unified Model (Davies et al., 2005). RTTOV-11 was run without water and ice clouds in the simulations such that the ash cloud was simulated in a clear sky (surface and atmospheric water vapour and temperature variations were still present).

Simulations were performed using meteorological data and ash clouds modelled by NAME from the Eyjafjallajökull eruption for 12:00 UTC on the following dates: 14 and 15 April and 6-9, 11, 13-17 May. In each case, the location, altitude and concentration of volcanic ash predicted by NAME were used. The concentration data were converted to number density assuming the same lognormal PSD in all pixels and interpolated onto the NWP grid for modelling. The interpolation is necessary because the atmospheric dispersion model, NAME, is run at a finer resolution than the NWP model. In a real ash cloud the size distribution would vary downwind from the volcano as grains are deposited (Rose et al., 2001); this is a topic for future studies of simulated imagery. As the aim of this study was to compare a range of PSD and weather conditions, comparisons were made on a pixel-by-pixel basis, and using a homogeneous cloud grain size does not affect our conclusion. The geometric standard deviation of the PSD $(\sigma)$ was fixed at 2.0, following Pavolonis et al. (2013) and in line with airborne measurements of the Eyjafjallajökull ash cloud ( $\sigma=1.8-2.5$; Turnbull et al., 2012; Johnson et al., 2012) and the mass median radius of the PSD was varied from $0.5-32 \mu \mathrm{m}$. The outputs are simulated brightness temperatures (BTs) for SEVIRI infrared channels. High concentrations of particles cause ash clouds to become opaque (Rose et al., 2001). In the simulations presented here, the concentration of ash was sufficiently low for the clouds to be optically semi-transparent, even when dominated by larger particles.
Retrievals were made on the simulated images using the method of Francis et al. (2012). The primary test for volcanic ash uses the brightness temperature difference method on the 10.8 and $12.0 \mu \mathrm{m}$ channels; additional pixels may be detected by tests using data from the $8.7 \mu \mathrm{m}$ channel and simulated water-vapour-corrected, clear-sky radiances, or removed by a test using the effective cloud emissivities and a spatial filtering test. Once ash-contaminated pixels have been identified, a retrieval of the physical properties is carried out using data from channels centred at 10.8, 12.0 and $13.4 \mu \mathrm{m}$ to obtain estimates for the ash layer pressure ( $p_{\text {ash }}$; a proxy for the altitude of the cloud), the ash column mass loading $(L)$, and the ash size distribution effective radius $\left(r_{\text {eff }}\right)$. The geometric standard deviation, $\sigma$, of the retrieved ash cloud was fixed at 2.0. These values can then be compared to the original input values (see Fig. 8 for methodology flowchart). The retrievals are carried out using a one-dimensional variational (1D-Var) framework, which attempts to reach a statistically optimal estimate of the three physical properties of ash ( $\left.p_{\mathrm{ash}}, L, r_{\mathrm{eff}}\right)$ consistent with the satellite data (real or simulated) and any prior background knowledge by minimising a cost function (Francis et al., 2012). The a priori effective radius used by the Met Office in an operational setting is $3.5 \mu \mathrm{m}$. The total cost of the solution describes how closely the result matches the measured radiances and (weak) a priori constraints. The lower the total cost, the better the fit of the modelled solution to the observations.

\subsection{Results}

Initial modelling using Mie theory shows that, for SEVIRI, a negative BTD can only occur for individual (or monodisperse) spherical andesite particles with radius less than $\sim 6 \mu \mathrm{m}$ and that the effect is strongest for particles with radius $<3 \mu \mathrm{m}$ (Fig. 7). Only these particles contribute to the BTD effect, and we refer to them here as "BTD-active". However, volcanic ash clouds contain particles with a range of sizes. Calculations using a lognormal PSD with geometric standard deviation $(\sigma)$ of 2.0 , show that a (weak) negative BTD is produced for distributions with mass median radius up to $21.5 \mu \mathrm{m}$. This corresponds to $r_{\text {eff }}=16.5 \mu \mathrm{m}$, which is in good agreement with Wen and Rose (1994). The sensitivity is low for mass median radii $>6 \mu \mathrm{m}$.

A comparison between the input and the retrieved ash parameters for two example grain-size distributions, with PSD mass median radius of 4 and $12 \mu \mathrm{m}$, is shown in Fig. 9a-c. It demonstrates the sensitivity of satellite identification of ashcontaining pixels and retrievals to grain size. In both cases, the retrieved effective radii are scattered across a range of values ( $\pm 3-8 \mu \mathrm{m}$ around the mean) due to variations in atmospheric, ground and ash cloud conditions (Fig. 9d, e). Fewer ash-containing pixels are detected when the grain size is coarser and the retrieved effective radius is an underestimate. In the case of missed pixels, a forecaster in an operational Volcanic Ash Advisory Centre (VAAC) setting may 

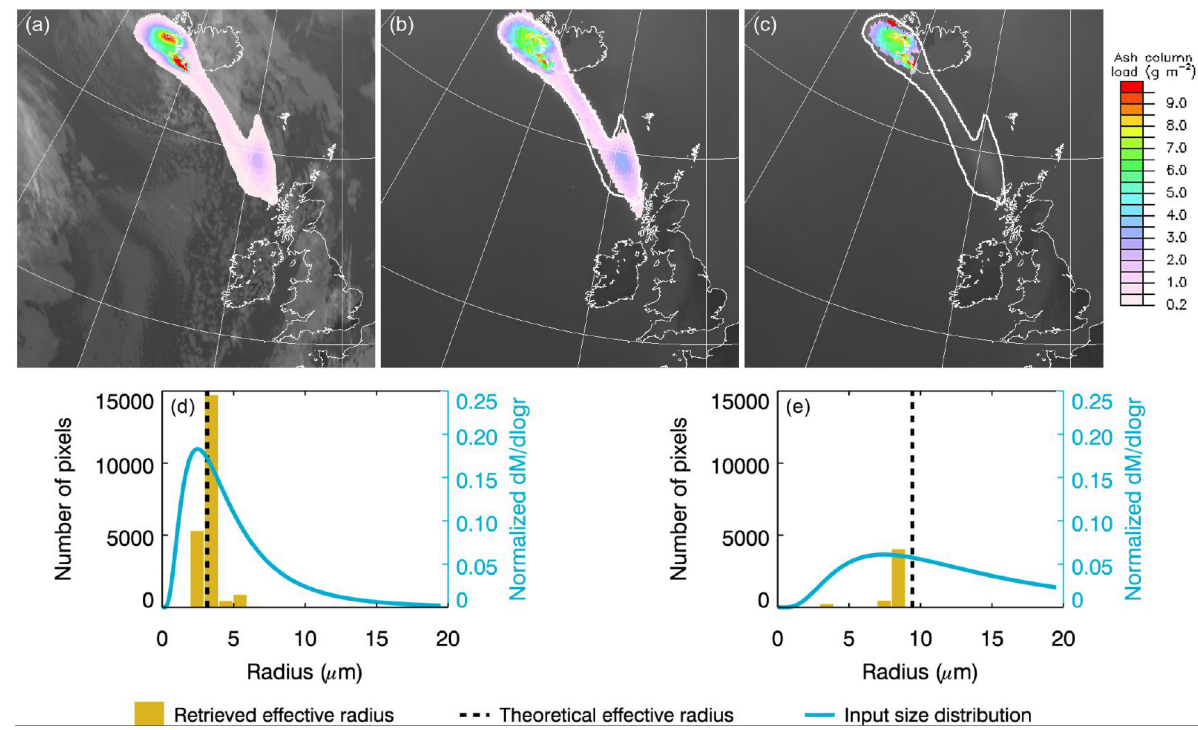

Figure 9. Ash mass loading and effective radius data for 12:00 UTC on 14 May 2010. (a) NAME ash column mass loading overlaid on the SEVIRI $10.8 \mu \mathrm{m}$ BT image for the corresponding time. (b) and (c) Retrieved ash column mass loading data from simulated SEVIRI infrared data using a lognormal PSD with geometric standard deviation of 2.0 and a mass median radius of 4 and $12 \mu \mathrm{m}$ respectively. The light grey line in (b) and (c) shows the extent of the NAME ash coverage (where mass loading $>0.2 \mathrm{~g} \mathrm{~m}^{-2}$ ); this is overlaid on a simulated $10.8 \mu \mathrm{m}$ infrared image (simulated without clouds). Slightly cooler temperatures indicate the presence of volcanic ash within the zone of NAME ash coverage, which may be identified by a skilled forecaster. (d) and (e) Histograms of retrieved effective radii from the same simulated SEVIRI data as (b) and (c) respectively. The blue curves in (d) and (e) show the input mass PSD, while the dotted line shows the corresponding theoretical effective radius.

still be able to identify a volcanic ash cloud because singlechannel infrared images can show the presence of cooler material in the ash-filled pixels and visible imagery may show scatter from the aerosols. However, it would not be detected by an automatic BTD method and no retrievals are possible.

Figure 10a shows the relationship between the mass median radius of the input PSD and the retrieved effective radius. There is large scatter in the retrieved effective radii, due to variations in the atmospheric and volcanic plume conditions. The mean value follows the theoretical line until the mass median radius increases beyond $\sim 10 \mu \mathrm{m}$. At larger sizes, the mean retrieved effective radius is lower than the theoretical effective radius and the underestimation increases as the mass median radius increases. The mean retrieved effective radius reaches a plateau at around $9 \mu \mathrm{m}$ as the infrared retrievals have reduced sensitivity to the increasing proportion of larger particles. This may explain a lack of published retrieved effective radii greater than this value (Grainger et al., 2013). As the mass median radius of the PSD increases it is increasingly difficult to find a solution. Above a mass median radius of $21.5 \mu \mathrm{m}$, ash-containing pixels are only detected by incorporating data from the $8.7 \mu \mathrm{m}$ channel and water vapour corrections (Francis et al., 2012); these would be missed by methods relying solely on the twochannel BTD. There are fewer ash-containing pixels in the simulated images that have well-fitting solutions in the retrieval (low cost values), so the density of values for these sizes is lower. At the largest grain sizes, many retrievals result in an effective radius closer to the a priori value set in the retrieval problem of $3.5 \mu \mathrm{m}$.

The effect of changing the a priori effective radius can be demonstrated by running the retrievals with a value of $15 \mu \mathrm{m}$ (Fig. 10b). This is much higher than the value used in an operational setting. Again, the mean value follows the theoretical line for particle distributions with mass median radius of $<6 \mu \mathrm{m}$, but the results are more scattered than in the $3.5 \mu \mathrm{m}$ case and there is a significant population of retrieved $r_{\text {eff }}$ values around 9-14 $\mu \mathrm{m}$. For input mass median radii of $6-22 \mu \mathrm{m}$, the retrieved effective radius is overestimated. Above this size the mean effective radius reaches a plateau at $16.7 \mu \mathrm{m}$, which is the theoretical maximum size at which a PSD can exhibit the BTD effect.

The averaging kernel (Rodgers, 2000; Thomas et al., 2009) of a retrieval can quantify its sensitivity to the a priori estimates. The averaging kernel elements and the degrees of freedom of signal were calculated for each retrieved pixel (see Supplement for plots and more details). Theoretically, these range from $0-1$ and $0-3$ respectively, where 1 and 3 represent a perfect retrieval controlled only by the true state of the system. Using the operational a priori parameters, the median averaging kernel elements for effective radius, mass loading and ash top pressure are $0.95,0.97$ and 0.84 . The median degrees of freedom of signal score is 2.7. This shows that retrievals are affected by the a priori estimates to some 
(a)

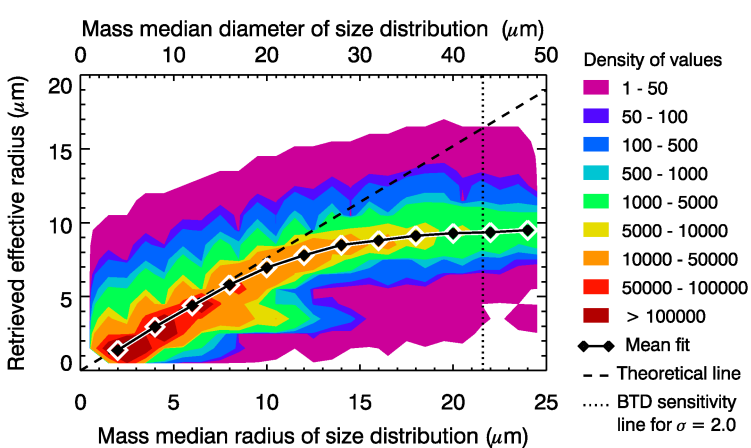

(b)

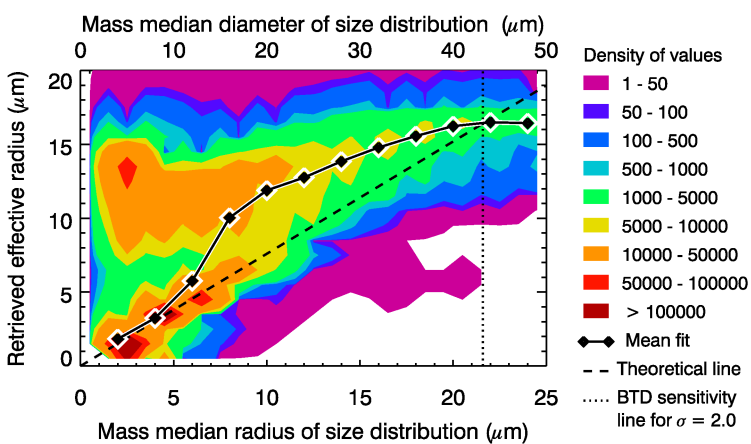

Figure 10. Retrieved effective radius for pixels where retrieved values give good fit to simulated images (i.e. total cost $<12$ ) and mass loading $>0.2 \mathrm{~g} \mathrm{~m}^{-2}$ against mass median radius of a lognormal PSD with geometric standard deviation of 2.0. The coloured contours represent the density of values from the pixels in the 12 simulated satellite images. The black diamonds are the mean retrieved effective radius for the given mass median radius of the PSD. The vertical dotted line shows the limit of sensitivity for the BTD method; ash-containing pixels in coarser PSDs were identified by additional tests. (a) The mean retrieved effective radius tracks the theoretical effective radius up to around $10 \mu \mathrm{m}$. PSDs that are coarser than this still return a mean effective radius of around $9 \mu \mathrm{m}$. There is a population of retrievals clustered around the a priori effective radius of $3.5 \mu \mathrm{m}$. (b) As above, but with a priori effective radius of $15 \mu \mathrm{m}$. This value is much higher than is used in practice, but the plot illustrates the sensitivity of the retrieval to the a priori estimate.

extent and that the mass loading and effective radius are more sensitive than the ash layer pressure to the true state of the system. Variations in averaging kernel elements with changing input parameters show that the retrieval is most sensitive to small particles (mass median input radius $<10 \mu \mathrm{m}$ ) and large mass loadings $\left(>2 \mathrm{~g} \mathrm{~m}^{-2}\right)$. The degrees of freedom of signal for pixels with concentrations corresponding to low contamination of airspace (mass loading of $0.2 \mathrm{~g} \mathrm{~m}^{-2}$ for a $1 \mathrm{~km}$ thick cloud) is $2.0-2.4$. Thus, the choice of a priori values is most important in distal clouds with low mass loadings, even though they are dominated by smaller particles.

The percentage of the input mass retrieved for a given mass median radius of the size distribution is shown in

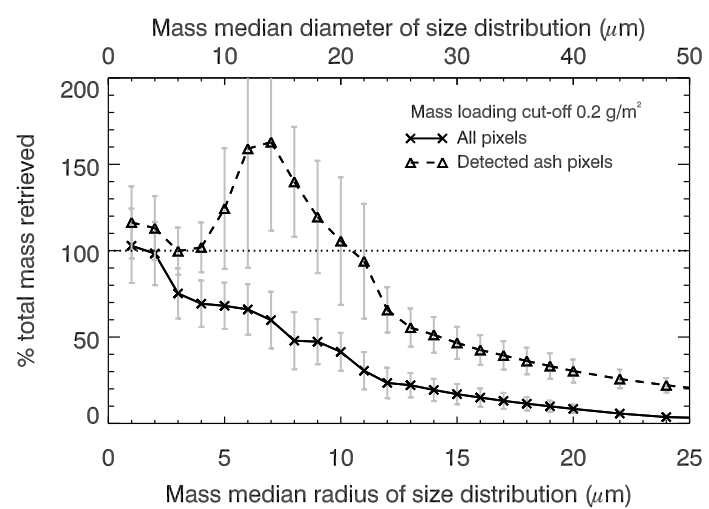

Figure 11. Retrieved mass loading for pixels where retrieved values give good fit to simulated images (i.e. total cost $<12$ ) against mass median radius of a lognormal PSD with a geometric standard deviation of 2.0. Data from all 12 cases are combined. Percentage of total mass retrieved is the sum of the retrieved total column loadings $\times$ area, divided by the total mass input into the simulated imagery from the NAME model. The dashed line includes only those for which volcanic ash was detected in the simulated imagery; the solid line includes all pixels that contained ash in the input NAME data. The error bars show the standard deviation of the data.

Fig. 11. The dashed line shows data from pixels correctly identified as containing ash and represents the accuracy of the retrieval method. The solid line compares the total ash input from the NAME model with the total mass retrieved and is sensitive to both the detection method and the retrieval method. Here, a cut-off mass loading value of $0.2 \mathrm{~g} \mathrm{~m}^{-2}$ was used. This is equivalent to a concentration of $0.2 \mathrm{mg} \mathrm{m}^{-3}$ for a $1 \mathrm{~km}$ ash cloud, which is the minimum concentration recorded on the ash concentration charts issued as supplementary charts by the London VAAC and has been suggested as the limit of sensitivity of the BTD method (Prata and Prata, 2012). For PSD with small geometric mass median radius of $1-2 \mu \mathrm{m}$, the detection and retrieval steps work very well and $\sim 100 \%$ of mass is retrieved. As the geometric mass median radius increases, the accurate identification of ash-contaminated pixels steadily decreases, with an approximately linear decrease of $5 \%$ per unit increase in geometric mass median radius. The retrievals tend to overestimate the mass loading for PSD with geometric mass median radii 6 $10 \mu \mathrm{m}$ by up to $60 \%$. At greater particle sizes the retrieved mass loadings decrease, so the combined effect of underestimated detection and underestimated retrievals result in the mass loadings being increasingly underestimated. For a PSD with a mass median radius of $12 \mu$ m only $\sim 65 \%$ of the mass is retrieved from pixels where ash is detected. This reduces to $<25 \%$ when considering all ash-contaminated pixels as many pixels that contain large ash particles are no longer identified. 


\section{Discussion}

\subsection{Cryptotephra transport to distal regions}

Icelandic cryptotephra are found across NW Europe and provide information on the grain size of particles carried to distal regions in volcanic plumes. Our tephrochronology results show that PSDs of cryptotephra long-axis lengths in the UK are lognormal, with very small proportions of theoretically BTD-active particles. The sizes are consistent with singlegrain measurements from around the world and with distal grain-size distributions from much larger eruptions (Table 1). This implies that grains $20-125 \mu \mathrm{m}$ are present in distal ash clouds, and that they comprise a larger fraction of the PSD closer to the volcano.

Most damaging ash-aircraft encounters occur within $24 \mathrm{~h}$ of the onset of an eruption (Guffanti et al., 2010). At wind velocities observed during recent eruptions (Table 4), an ash plume could travel $500-1600 \mathrm{~km}$ in this time and our model results confirm the potential for cryptotephra-sized grains to remain airborne to these distances, even from moderately sized eruptions. The transport models also highlight the moderate effect of incorporating sphericity, density and atmospheric stratification on terminal velocity calculations. The effect of using measured fall velocities from Riley et al. (2003) is larger and can result in a 3 times increase in particle travel range compared to dense spheres (note: uncertainty on this figure may be high as error data were not available). When comparing volcanic ash grains of different compositions, our calculations also show that rhyolite grains are more likely to reach the UK than basaltic ones (see Supplement), which may partly explain the dominance of rhyolitic grains in European cryptotephra, despite explosive basaltic eruptions being more common in Iceland (Lawson et al., 2012). Our modelling results show that transport of cryptotephrasized volcanic ash grains to distal regions should be expected, even from moderately sized eruptions.

The PSD within ash clouds is not well constrained; this is an important question in understanding distal transport of volcanic ash. Our results indicate that cryptotephra-sized grains should be present in distal ash clouds, while the assumption of Mie scattering by dense spheres implies that any ash cloud exhibiting a BTD is dominated by grains $<10 \mu \mathrm{m}$ in diameter. Satellite PSDs overlap with the lower size range of cryptotephra PSDs, so these views may be consistent in distal regions. For example, Prata and Prata (2012) retrieved an $r_{\text {eff }}$ of $5.6 \mu \mathrm{m}$ for an ash cloud near the Faroe Islands from Eyjafjallajökull eruption on 15 April 2010. Assuming a lognormal distribution with $\sigma=2.0,50 \%$ of the plume mass is contained in particles $<14.3 \mu \mathrm{m}$ in diameter (and up to $95 \%$ is within particles $<44.5 \mu \mathrm{m}$ ). This is compatible with the median equivalent area diameter of particles deposited in the Faroe Islands by the Eyjafjallajökull eruption $(40 \mu \mathrm{m}$; see Fig. 2b), but does not account for the largest particles or ag- gregates (> $100 \mu \mathrm{m}$; Stevenson et al., 2012). This agreement is less likely in proximal clouds.

\subsection{Limitations of aircraft measurements of volcanic ash PSD}

Published PSDs for airborne ash clouds are mostly limited to distal plumes, or to areas of low ash concentration around the plume margins and may also be limited by the sampling method. For example, the plume from the Eyjafjallajökull 2010 eruption was sampled by the UK's Facility for Airborne Atmospheric Measurements (FAAM) aircraft and by the Deutsches Zentrum für Luft- und Raumfahrt (DLR) Falcon aircraft. Both aircraft used wing-mounted sensors that estimate the grain size of particles via optical scattering with nominal ranges of $0.6-50 \mu \mathrm{m}$ (CAS instrument on FAAM) and 1-25 $\mu$ m (FSSP-300 instrument on DLR Falcon). They also carried cloud imaging probes (CIP-15 with size range $15-930 \mu \mathrm{m}$ on FAAM and 2D-C with range $25-800 \mu \mathrm{m}$ on the DLR Falcon) that could detect much larger particles. Neither aircraft sampled the most concentrated parts of the plume during or immediately after the most explosive phases of the eruption (14-17 April, 56 May; Gudmundsson et al., 2012). FAAM reported that the most-concentrated ash $\left(>600 \mu \mathrm{g} \mathrm{m}^{-3}\right)$ was measured $700 \mathrm{~km}$ downwind on 14 May 2010 and contained particles up to $35 \mu \mathrm{m}$ diameter (Johnson et al., 2012). The DLR Falcon sampled the plume repeatedly, recording concentrations up to $765 \mu \mathrm{g} \mathrm{m}^{-3}$ with grain sizes up to $\sim 20 \mu \mathrm{m}$ diameter (Schumann et al., 2010). In both cases, much coarser particles were detected associated with meteorological clouds, but these were interpreted as water/ice. In another example, volcanic ash particles were identified on the air filters of the cabin cooling system of the NASA DC-8 aircraft that flew through ash from the Hekla 2000 eruption at a distance of $1500 \mathrm{~km}$ from the volcano. Ash grains were $1-10 \mu \mathrm{m}$ in length (Pieri et al., 2002), but it is not clear if this is representative of the size in the cloud.

The lack of coarser cryptotephra-sized grains in these results may be a consequence of sampling during weak phases of eruptions and outside the highest concentration regions in the centre of the plume. The coarsest grains are likely to be deposited from the climactic phases of eruptions and from the most concentrated parts of their plumes. Alternatively, coarser ash grains may be associated with ice as hydrometeors (Durant et al., 2009), especially if an eruption was subglacial, with large quantities of water at the vent.

The grain-size distribution within more concentrated plumes closer to the volcanoes was measured by Hobbs et al. (1991). A $10 \mathrm{~km}$ high plume from Mount Redoubt was sampled on 8 January 1990 at a location $130 \mathrm{~km}$ downwind, when the cloud was $2.5 \mathrm{~h}$ old. Measurements were made with a forward light-scattering particle size instrument with a stated range of $2-47 \mu \mathrm{m}$. The measured distribution contains parti- 
cles of all sizes from $<1 \mu \mathrm{m}$ and is dominated by those in the 10-30 $\mu \mathrm{m}$ size range.

However, there is evidence that this does not represent the true size distribution within the plume. The shape of the size distribution (and those from the Mount St Helens and St Augustine eruptions, also measured by Hobbs et al., 1991) shows that it has been truncated so as to contain no particles coarser than $40 \mu \mathrm{m}$. This is due to the upper size limit of the instrument and is why all emission fluxes were reported as corresponding to particles $<48 \mu \mathrm{m}$ diameter. In fact, it can be expected that $50 \%$ of the material erupted during a short-lived, subplinian andesite eruption such as the 8 January 1990 Redoubt eruption, will have a grain size coarser than $100 \mu \mathrm{m}$ (e.g. Mount Spurr 1992; Durant et al., 2009), and that these particles will still be airborne after just $2.5 \mathrm{~h}$. This was demonstrated by the encounter between flight KLM867 and the ash from a previous eruption of Mount Redoubt on 15 December 1989, which took place further downwind, at a distance of $280 \mathrm{~km}$ from the volcano. Analysis of the aircraft found "heavy contamination" of the engine oil with particles up to $60 \mu \mathrm{m}$ and a "substantial population" of $100 \mu \mathrm{m}$ particles on the aircraft exterior (Casadevall, 1994). Thus the distributions presented in Hobbs et al. (1991) underestimate the concentration of cryptotephra-sized particles (and coarser) in the airborne plume. This is important because they are commonly used by VAACs to initialise atmospheric dispersion models (e.g. Webster et al., 2012).

\subsection{Factors affecting satellite retrievals}

Analysis of simulated satellite infrared images presented here shows that the retrieval algorithm performs best for simulated clouds with mass median radius less than $5 \mu \mathrm{m}$. This corresponds to particles $<10 \mu$ m diameter, which have the highest differential absorption between the two infrared bands. When using the Met Office operational settings in the retrieval algorithm with an a priori effective radius of $3.5 \mu \mathrm{m}$, the retrieved effective radii are systematically underestimated in clouds with mass median radii greater than $\sim 10 \mu \mathrm{m}$. This discrepancy arises because the retrieval problem is ill posed, with many possible combinations of $r_{\mathrm{eff}}$, mass loading, cloud height and meteorological parameters that would cause the observed (or simulated) BTD signal. Analysis of the averaging kernel (see Supplement for details) shows that the choice of a priori effective radius becomes more important as the ash cloud concentration and the proportion of BTD-active particles decrease, causing a reduction in the influence of the observations on the retrieval. Using a high a priori effective radius of $15 \mu \mathrm{m}$ causes overestimation of retrieved effective radius for mass median radius above $5 \mu \mathrm{m}$. Our results apply to the method of Francis et al. (2012), but the higher sensitivity of the BTD method to the finest grain sizes and the absence of published $r_{\text {eff }}$ values greater than $10 \mu \mathrm{m}$, even in proximal plumes, indicate that it is likely to be a feature of all similar retrieval algorithms. The results also highlight how incorporating meteorological information and brightness temperatures from other infrared channels allows ash-containing pixels to be identified that would otherwise be missed using the BTD method alone. As hyperspectral infrared satellite data become more widely available (e.g. Gangale et al., 2010), using information from the extra bands may better constrain retrievals.

Systematic underestimation of ash cloud mass is a result of both the reduced detection rate of ash-filled pixels containing large particles and the underestimation of the mass loading within pixels that are correctly identified as ash-filled but that contain large particles. This has implications for our understanding of plume processes, as satellite data are used to track decreasing plume mass via deposition and to estimate the proportion transported to distal areas (Rose et al., 2000, 2001), and thus our understanding of sedimentation from volcanic plumes. Reliable ash cloud mass data are also important for aviation safety. The London VAAC uses estimates of the distally transported mass proportion to initialise the NAME dispersion model (Webster et al., 2012). Satellitederived mass loadings are also increasingly used directly for advice to the aviation industry and in inversion modelling (e.g. Stohl et al., 2011). It is therefore important that the bias towards small particle sizes and low mass loadings is incorporated into any interpretation of satellite retrievals.

Meteorological factors complicate retrievals, both in simulations and real-life clouds. The main effect is to add noise, causing the retrieved $r_{\text {eff }}$ from a single input distribution to have a range of values. For this reason, we recommend that histograms of retrieved effective radius from many pixels across the cloud should not be presented in a manner in which they could be mistaken for the grain-size distribution in the cloud. In a real plume, high atmospheric water vapour loading can produce positive BTDs, while temperature inversions above ice-covered land surfaces can produce negative BTDs (Prata et al., 2001). Furthermore, the presence of volcanic gases or ice forming upon ash particles may also affect the BTD signal. Our simulations were carried out without water and ice clouds. Including them in the simulations is likely to decrease the number of pixels in which ash was successfully detected. This was the finding of Kylling et al. (2013), who reported that detection was difficult when ash clouds were mixed with, or located only slightly above, water clouds.

The simulations consider an idealised situation where ash particles are assumed to be dense spheres that scatter infrared light according to Mie theory. Existing methods for retrievals from volcanic ash clouds also use this assumption, which dictates that any cloud exhibiting a BTD will be interpreted as having a PSD dominated by particles $<10 \mu \mathrm{m}$ in diameter. Recently, investigations using computer models of the optical properties of non-spherical, vesicular particles shows that irregular particles can produce negative BTD at coarser grain sizes than dense spheres (up to $20 \mu \mathrm{m}$ diameter; Kylling et al., 2014). The same study also concludes that the assumption 
of dense spherical particles can underestimate the retrieved mass by $30 \%$ compared with porous spheres and that uncertainty in particle shape increases the error to $50 \%$. This is a physical factor that may explain why retrievals are possible from proximal clouds that should be too coarse to exhibit a BTD effect (e.g. Ruapehu 1996, Eyjafjallajökull 2010; Prata and Grant, 2001; Bonadonna et al., 2011). Real ash particles (such as those in Fig. 4) are even more irregular than those modelled by Kylling et al. (2014). It may be possible for a platy ash grain $5 \mu \mathrm{m}$ thick to exhibit the BTD effect, despite having a length and width that would be reported by tephrochronologists of 50-100 $\mu \mathrm{m}$. Making a retrieval on an ash cloud containing such grains on the assumption of dense spheres will lead to a systematic, and potentially significant, underestimation of the particle size. Current refractive index data have been measured from thin sections (e.g. Pollack et al., 1973) or from grains sieved to less than $<22.5 \mu \mathrm{m}$ in size (Grainger et al., 2013). Further quantitative, empirical data on the optical properties of ash samples of varied size, shape and composition are required to better-constrain this effect. Given the large difference between fall velocities of real and simulated ash particles, these would ideally be combined with measurements of aerodynamic properties, thus improving dispersion modelling inputs, too.

\section{Conclusions}

We have reviewed and supplemented the evidence that volcanic ash particles $20-125 \mu \mathrm{m}$ in length can be transported $>500 \mathrm{~km}$ from their source volcanoes. We also used simple models to show that this is to be expected, even from moderately sized eruptions. These results highlight a discrepancy between the size of volcanic ash particles reported by tephrochronologists and by satellite remote sensing. We suggest three reasons for this that add to our understanding of the difference between the two results.

The first is the way that tephrochronologists measure and report grain size. Two factors cause reporting of slightly higher grain sizes compared to remote sensing methods. Firstly, the long-axis length measurements made by tephrochronologists are around 1.5 times the equivalent area diameter of the same particles. Secondly, as manually measured cryptotephra size distributions are lognormal, when tephrochronologists report the arithmetic mean grain size it gives the impression that the modal grain size is larger than it is. We recommend that the geometric mean and standard deviation are used in future. Comparison of grain-size distributions measured by optical microscope (lower size limit of $10-15 \mu \mathrm{m}$ ) with those measured by laser particle size analyser (range of 0.4-2000 $\mu \mathrm{m}$ ) demonstrates that modal grain size is still captured correctly by manual measurements. Difficulty in identifying the smallest grains is therefore not a large source of error in reported cryptotephra sizes.
The second reason is that $r_{\text {eff }}$ represents a size distribution extending to much coarser grain sizes. For example, where $r_{\text {eff }}=8 \mu \mathrm{m}$ and the geometric standard deviation $\sigma$ is 2.0, $95 \%$ of the mass is contained in particles $<64 \mu \mathrm{m}$. For this reason, $\sigma$ should always be reported alongside $r_{\text {eff }}$ values and histograms of $r_{\text {eff }}$ should not be presented in a way that could be misunderstood as a PSD. Cryptotephra grains may therefore be represented by the coarse tail of the distribution, and distal aircraft measurements of dilute ash clouds from weak eruptions are consistent with this. It should be noted that there are no reliable published grain-size distributions obtained by direct sampling within concentrated (e.g. $1 \mathrm{~g} \mathrm{~m}^{-3}$ ) ash clouds. Cryptotephra-sized grains within the coarse tail of the distribution cannot be the whole explanation, however, as $r_{\text {eff }}$ values of 10-17, which are theoretically possible, are not reported in the literature, even for proximal clouds.

Retrievals carried out on simulated satellite infrared imagery illustrate a third reason: low $r_{\text {eff }}$ values can result from systematic underestimation by retrieval algorithms. This occurs because infrared data are most sensitive to particles $<6 \mu \mathrm{m}$ in radius. Where these represent a small proportion of the simulated ash cloud, the solution is poorly constrained and the a priori choice of retrieved effective radius becomes more important. Solutions dominated by small, strongly BTD-active particles require relatively low ash column loadings to generate the same BTD effect as those containing large, non-BTD-active particles, so this can also lead to underestimation in the retrieved ash cloud mass. This is an important consideration for VAACs as the combined effect of undetected pixels and underestimation of retrieved mass loading causes over $50 \%$ of the mass of the cloud to be missed.

The above reasons are still insufficient to explain why proximal clouds often produce a BTD signal, or the 10 times discrepancy between ground- and satellite-based estimates of deposit mass in proximal areas. We hypothesise that this results from the physics of infrared scattering by vesicular and highly irregular volcanic ash particles. Under the dense spheres approximation, any BTD signal is assumed to result from particles with diameter $<12 \mu \mathrm{m}$. The largest distal tephra grains have a platy morphology and can be 50 $100 \mu \mathrm{m}$ long, but $<5 \mu \mathrm{m}$ thick; it may be possible that they contribute to the BTD effect in certain orientations. Kylling et al. (2014) demonstrated that simulated spherical particles containing bubbles could exhibit a BTD effect up to $20 \mu \mathrm{m}$ diameter. We suggest that empirical, quantitative studies into the optical and aerodynamic properties of volcanic ash grains of varied composition and size are essential to address this problem. 


\section{Appendix A: Particle size distributions and the effective radius}

The size distribution of airborne volcanic ash is typically modelled as lognormal, as defined by

$n(r)=\frac{N_{0}}{\sqrt{2 \pi}} \frac{1}{\ln (\sigma)} \frac{1}{r} \exp \left(-\frac{\left(\ln r-\ln r_{m}\right)^{2}}{2 \ln ^{2}(\sigma)}\right)$,

where $N_{0}$ is the total number density, $r$ is the particle radius and $r_{n}$ is the number median radius (which is equal to the number geometric mean radius). There is frequently confusion, particularly across different subjects, in the meaning of $\sigma$ and so care must be taken when comparing size distributions in the literature. In this formulation, $\sigma$ is the geometric standard deviation, such that $\ln (\sigma)$ is the standard deviation of the logarithms of the grain sizes, and $95.5 \%$ of the distribution lies within the range $r_{n} / \sigma^{2}$ to $r_{n} \cdot \sigma^{2}$ (Limpert et al., 2001). Values of $\sigma$ of $\sim 2$ are commonly used to describe the PSD of volcanic ash clouds (Pavolonis et al., 2013).

It can be shown that the particle size distribution in terms of mass is also lognormal (Seinfeld and Pandis, 2006), with the same geometric standard deviation, $\sigma$, and with a mass median radius $r_{m}$ related to the number median radius $r_{n}$ by

$r_{m}=r_{n} \exp \left(3 \ln ^{2} \sigma\right)$

The effective radius is the size of particle in a uniformly sized suspension of that scatters infrared in an equivalent manner to the combined effect of all particle sizes in a size distribution. It is calculated by

$$
r_{\mathrm{eff}}=\frac{\int_{0}^{\infty} r^{3} n(r) \mathrm{d} r}{\int_{0}^{\infty} r^{2} n(r) \mathrm{d} r}
$$

where $r$ is the particle radius and $n(r)$ is the number density per unit radius. The effective radius for the lognormal size distribution in terms of number median radius and geometric standard deviation is

$r_{\text {eff }}=r_{n} \exp \left(\frac{5}{2} \ln ^{2} \sigma\right)$.

For a PSD with geometric standard deviation $(\sigma)$ of 2.0, the effective radius is therefore equal to 3.32 times the number median radius $\left(r_{n}\right)$ and 0.79 times the mass median radius $\left(r_{m}\right)$. Curves showing the grain-size distributions that correspond to different effective radii are shown in Fig. 1.

\section{Appendix B: Equations for terminal velocity of non-spherical particles}

The terminal fall velocity $\left(W_{\mathrm{T}}\right)$ of a single particle falling in air is given by (Maryon et al., 1999)

$W_{\mathrm{T}}=\left(\frac{4}{3} \frac{D}{C_{\mathrm{D}}} g \frac{\rho_{\mathrm{P}}-\rho}{\rho}\right)^{1 / 2}$,

where $D$ is the particle diameter, $C_{\mathrm{D}}$ is the drag coefficient, $g$ is gravitational acceleration, $\rho$ is fluid density and $\rho_{\mathrm{P}}$ is particle density. Equation (B1) can be applied to all particle shapes and Reynolds numbers $(R e)$ by defining an appropriate drag coefficient $\left(C_{\mathrm{D}}\right)$ and taking the particle diameter to be that of an equivalent sphere with the same volume $\left(D_{\mathrm{v}}\right)$. For spherical particles at low Reynolds numbers (i.e. $R e \ll 1$ ), $C_{\mathrm{D}}=24 / R e$ and Eq. (B1) simplifies to Stokes' law. This was used for the simplest scheme and is appropriate for particles up to $100 \mu \mathrm{m}$ diameter. For the more realistic scenario, the drag coefficient $\left(C_{\mathrm{D}}\right)$ for non-spherical particles was calculated using the scheme presented by Ganser (1993) as recommended by Alfano et al. (2011) and described by

$$
\begin{aligned}
C_{\mathrm{D}}= & \frac{24}{\operatorname{Re} K_{1}}\left(1+0.1118\left[\operatorname{Re}\left(K_{1} K_{2}\right)\right]^{0.6567}\right) \\
& +\frac{0.4305 K_{2}}{1}+\frac{3305}{\operatorname{Re} K_{1} K_{2}} \\
K_{1}= & \frac{3}{1+2 \Psi_{\mathrm{R}}^{-0.5}} \\
K_{2}= & 10^{1.84148\left(-\log \Psi_{\mathrm{R}}\right)^{0.5743} .}
\end{aligned}
$$

$R e=\frac{\rho W_{\mathrm{T}} D_{\mathrm{V}}}{\eta}$ is the Reynolds number and $\eta$ is the fluid viscosity. The particle morphology is characterised using the sphericity parameter $\left(\Psi_{R}\right)$, which is defined in 2-D by Riley et al. (2003, Eq. B5) as the ratio between the projected area $\left(A_{\mathrm{P}}\right)$ and the square of the projected perimeter $\left(P_{\mathrm{P}}\right)$ :

$\Psi_{R}=\frac{4 \pi A_{\mathrm{P}}}{P_{\mathrm{P}}^{2}}$. 


\section{The Supplement related to this article is available online at doi:10.5194/amt-8-2069-2015-supplement.}

Acknowledgements. John A. Stevenson is funded by The Royal Society of Edinburgh via a Scottish Government/Marie Curie Actions Personal Research Fellowship. The Askja 1875 sample was provided by Jan Mangerud. The RTTOV model is developed as part of the EUMETSAT-funded NWP SAF activities. Frances M. Beckett would like to thank Claire Witham, Matthew Hort and the ADAQ group at the Met Office for their support and guidance. Sarah C. Millington would like to thank Pete Francis for his guidance throughout this work, and Fiona Smith for her help with the averaging kernels. Andrew Bell had useful comments on fitting particle size distributions. Hugh Pumphrey provided helpful comments on inversion techniques. We thank three anonymous reviewers for their comments on a previous version of the paper, and two anonymous reviewers and A. J. A. Smith et al. for comments on the discussion paper.

Edited by: A. Kokhanovsky

\section{References}

Abbott, P. and Davies, S.: Volcanism and the Greenland icecores: the tephra record, Earth-Sci. Rev., 115, 173-191, doi:10.1016/j.earscirev.2012.09.001, 2012.

Abbott, P. M., Davies, S. M., Steffensen, J. P., Pearce, N. J. G., Bigler, M., Johnsen, S. J., Seierstad, I. K., Svensson, A., and Wastegard, S.: A detailed framework of marine isotope stages 4 and 5 volcanic events recorded in two Greenland ice-cores, Quaternary Sci. Rev., 36, 59-77, doi:10.1016/j.quascirev.2011.05.001, 2012.

Alfano, F., Bonadonna, C., Delmelle, P., and Costantini, L.: Insights on tephra settling velocity from morphological observations, J. Volcanol. Geoth. Res., 208, 86-98, doi:10.1016/j.jvolgeores.2011.09.013, 2011.

Bergman, J., Wastegard, S., Hammarlund, D., Wohlfarth, B., and Roberts, S.: Holocene tephra horizons at Klocka Bog, westcentral Sweden: aspects of reproducibility in subarctic peat deposits, J. Quaternary Sci., 19, 241-249, doi:10.1002/jqs.833, 2004.

Blockley, S., Lane, C., Lotter, A., and Pollard, A.: Evidence for the presence of the Vedde Ash in Central Europe, Quaternary Sci. Rev., 26, 3030-3036, doi:10.1016/j.quascirev.2007.09.010, 2007.

Bonadonna, C. and Houghton, B.: Total grain-size distribution and volume of tephra-fall deposits, B. Volcanol., 67, 441-456, 2005.

Bonadonna, C. and Phillips, J. C.: Sedimentation from strong volcanic plumes, J. Geophys. Res., 108, 2340, doi:10.1029/2002JB002034, 2003.

Bonadonna, C., Genco, R., Gouhier, M., Pistolesi, M., Cioni, R., Alfano, F., Hoskuldsson, A., and Ripepe, M.: Tephra sedimentation during the 2010 Eyjafjallajökull eruption (Iceland) from deposit, radar, and satellite observations, J. Geophys. Res.-Sol. Ea., 116, B12202, doi:10.1029/2011JB008462, 2011.
Bramham-Law, C. W. F., Theuerkauf, M., Lane, C. S., and Mangerud, J.: New findings regarding the Saksunarvatn Ash in Germany, J. Quaternary Sci., 28, 248-257, doi:10.1002/jqs.2615, 2013.

Carey, S. N. and Sigurdsson, H.: Influence of particle aggregation on deposition of distal tephra from the MAy 18, 1980, eruption of Mount St. Helens volcano, J. Geophys. Res.-Sol. Ea., 87, 70617072, doi:10.1029/JB087iB08p07061, 1982.

Casadevall, T. J.: The 1989-1990 eruption of Redoubt Volcano, Alaska: impacts on aircraft operations, J. Volcanol. Geoth. Res., 62, 301-316, doi:10.1016/0377-0273(94)90038-8, 1994.

Colette, A., Favez, O., Meleux, F., Chiappini, L., Haeffelin, M., Morille, Y., Malherbe, L., Papin, A., Bessagnet, B., Menut, L., Leoz, E., and Rouill, L.: Assessing in near real time the impact of the April 2010 Eyjafjallajökull ash plume on air quality, Atmos. Environ., 45, 1217-1221, doi:10.1016/j.atmosenv.2010.09.064, 2011.

Coulter, S. E., Turney, C. S. M., Kershaw, P., and Rule, S.: The characterization and significance of a MIS 5a distal tephra on mainland Australia, Quaternary Sci. Rev., 28, 1825-1830, doi:10.1016/j.quascirev.2009.04.018, 2009.

Coulter, S. E., Pilcher, J., Plunkett, G., Baillie, M., Hall, V., Steffensen, J., Vinther, B., Clausen, H., and Johnsen, S.: Holocene tephras highlight complexity of volcanic signals in Greenland ice cores, J. Geophys. Res.-Atmos., 117, D21303, doi:10.1029/2012JD017698, 2012.

Dacre, H. F., Grant, A. L. M., and Johnson, B. T.: Aircraft observations and model simulations of concentration and particle size distribution in the Eyjafjallajökull volcanic ash cloud, Atmos. Chem. Phys., 13, 1277-1291, doi:10.5194/acp-13-12772013, 2013.

Davies, S., Turney, C., and Lowe, J.: Identification and significance of a visible, basalt-rich Vedde Ash layer in a Late-glacial sequence on the Isle of Skye, Inner Hebrides, Scotland, J. Quaternary Sci., 16, 99-104, doi:10.1002/jqs.611, 2001.

Davies, T., Cullen, M., Malcolm, A., Mawson, M., Staniforth, A., White, A. A., and Wood, N.: A new dynamical core for the Met Office's global and regional modelling of the atmosphere, Q. J. Roy. Meteor. Soc., 608, 1759-1782, 2005.

De Angelis, M., Fehrenbach, L., Jéhanno, C., and Maurette, M.: Micrometre-sized volcanic glasses in polar ices and snows, Nature, 317, 52-54, doi:10.1038/317052a0, 1985.

Delene, D. J., Rose, W. I., and Grody, N. C.: Remote sensing of volcanic ash clouds using special sensor microwave imager data, J. Geophys. Res.-Sol. Ea., 101, 11579-11588, doi:10.1029/96JB00643, 1996.

Devenish, B., Thomson, D., Marenco, F., Leadbetter, S., Ricketts, H., and Dacre, H.: A study of the arrival over the United Kingdom in April 2010 of the Eyjafjallajökull ash cloud using ground-based lidar and numerical simulations, Atmos. Environ., 48, 152-164, doi:10.1016/j.atmosenv.2011.06.033, 2012.

Dugmore, A.: Icelandic volcanic ash in Scotland, Scot. Geogr. Mag., 105, 168-172, doi:10.1080/14702548908554430, 1989.

Dugmore, A., Newton, A., Edwards, K., Larsen, G., Blackford, J., and Cook, G.: Long-distance marker horizons from smallscale eruptions: British tephra deposits from the AD 1510 eruption of Hekla, Iceland, J. Quaternary Sci., 11, 511-516, 1996.

Dunbar, N. W. and Kurbatov, A. V.: Tephrochronology of the Siple Dome ice core, West Antarctica: correla- 
tions and sources, Quaternary Sci. Rev., 30, 1602-1614, doi:10.1016/j.quascirev.2011.03.015, 2011.

Durant, A. J., Rose, W. I., Sarna-Wojcicki, A. M., Carey, S., and Volentik, A. C. M.: Hydrometeor-enhanced tephra sedimentation: constraints from the 18 May 1980 eruption of Mount St. Helens, J. Geophys. Res.-Sol. Ea., 114, B03204, doi:10.1029/2008JB005756, 2009.

Durant, A. J., Villarosa, G., Rose, W. I., Delmelle, P., Prata, A. J., and Viramonte, J. G.: Long-range volcanic ash transport and fallout during the 2008 eruption of Chaiten volcano, Chile, Phys. Chem. Earth, 45-46, 50-64, doi:10.1016/j.pce.2011.09.004, 2012.

Eliasson, J., Yoshitani, J., Weber, K., Yasuda, N., Iguchi, M., and Vogel, A.: Airborne measurement in the ash plume from Mount Sakurajima: analysis of gravitational effects on dispersion and fallout, Int. J. Atmos. Sci., 2014, 1-16, doi:10.1155/2014/372135, 2014.

Engwell, S. L., Sparks, R. S. J., and Aspinall, W. P.: Quantifying uncertainties in the measurement of tephra fall thickness, J. Appl. Volcanol., 2, 5, doi:10.1186/2191-5040-2-5, 2013.

Francis, P. N., Cooke, M. C., and Saunders, R. W.: Retrieval of physical properties of volcanic ash using Meteosat: a case study from the 2010 Eyjafjallajökull eruption, J. Geophys. Res.-Atmos., 117, D00U09, doi:10.1029/2011JD016788, 2012.

Gangale, G., Prata, A., and Clarisse, L.: The infrared spectral signature of volcanic ash determined from high-spectral resolution satellite measurements, Remote Sens. Environ., 114, 414-425, doi:10.1016/j.rse.2009.09.007, 2010.

Ganser, G. H.: A rational approach to drag prediction of spherical and nonspherical particles, Powder Technol., 77, 143-152, 1993.

Grainger, R. G., Peters, D. M., Thomas, G. E., Smith, A. J. A., Siddans, R., Carboni, E., and Dudhia, A.: Measuring volcanic plume and ash properties from space, Geol. Soc. Spec. Publ., 380, 293320, doi:10.1144/SP380.7, 2013.

Gudmundsson, M. T., Thordarson, T., Höskuldsson, A., Larsen, G., Björnsson, H., Prata, F. J., Oddsson, B., Magnússon, E., Högnadóttir, T., Petersen, G. N., Hayward, C. L., Stevenson, J. A., and Jónsdóttir, I.: Ash generation and distribution from the April-May 2010 eruption of Eyjafjallajökull, Iceland, Scientific Reports, 2, 572, doi:10.1038/srep00572, 2012.

Guffanti, M., Casadevall, T. J., and Budding, K.: Encounters of Aircraft with Volcanic Ash Clouds: A Compilation of Known Incidents, 1953-2009., Tech. rep., US Geological Survey, 2010.

Hall, V. and Pilcher, J.: Late-quaternary Icelandic tephras in Ireland and Great Britain: detection, characterization and usefulness, Holocene, 12, 223-230, 2002.

Hayward, C.: High spatial resolution electron probe microanalysis of tephras and melt inclusions without beaminduced chemical modification, Holocene, 22, 119-125, doi:10.1177/0959683611409777, 2012.

Hobbs, P. V., Radke, L. F., Lyons, J. H., Ferek, R. J., Coffman, D. J., and Casadevall, T. J.: Airborne measurements of particle and gas emissions from the 1990 volcanic eruptions of Mount Redoubt, J. Geophys. Res.-Atmos., 96, 18735-18752, doi:10.1029/91JD01635, 1991.

Housley, R. A., MacLeod, A., Nalepka, D., Jurochnik, A., Masojć, M., Davies, L., Lincoln, P. C., Bronk Ramsey, C., Gamble, C. S., and Lowe, J. J.: Tephrostratigraphy of a Lateglacial lake sediment sequence at Węgliny, southwest Poland, Quater- nary Sci. Rev., 77, 4-18, doi:10.1016/j.quascirev.2013.07.014, 2013.

Jennings, A., Thordarson, T., Zalzal, K., Stoner, J., Hayward, C., Geirsdóttir, Á., and Miller, G.: Holocene tephra from Iceland and Alaska in SE Greenland Shelf Sediments, Geological Society, London, Special Publications, 398, SP398.6, doi:10.1144/SP398.6, 2014.

Jensen, B. J. L., Pyne-O’Donnell, S., Plunkett, G., Froese, D. G., Hughes, P. D. M., Sigl, M., McConnell, J. R., Amesbury, M. J., Blackwell, P. G., van den Bogaard, C., Buck, C. E., Charman, D. J., Clague, J. J., Hall, V. A., Koch, J., Mackay, H., Mallon, G., McColl, L., and Pilcher, J. R.: Transatlantic distribution of the Alaskan White River Ash, Geology, 42, 875-878, doi:10.1130/G35945.1, 2014.

Johnson, B., Turnbull, K., Brown, P., Burgess, R., Dorsey, J., Baran, A. J., Webster, H., Haywood, J., Cotton, R., Ulanowski, Z., Hesse, E., Woolley, A., and Rosenberg, P.: In situ observations of volcanic ash clouds from the FAAM aircraft during the eruption of Eyjafjallajökull in 2010, J. Geophys. Res.-Atmos., 117, D00U24, doi:10.1029/2011JD016760, 2012.

Jones, A., Thomson, D., Hort, M., and Devenish, B.: The UK Met Office's Next-Generation Atmospheric Dispersion Model, NAME III, in: Air Pollution Modeling and Its Application XVII, edited by: Borrego, C. and Norman, A.-L., 580-589, Springer US, Boston, MA, 2006.

Jude-Eton, T., Thordarson, T., Gudmundsson, M., and Oddsson, B.: Dynamics, stratigraphy and proximal dispersal of supraglacial tephra during the ice-confined 2004 eruption at Grímsvötn Volcano, Iceland, Bulletin of Volcanology, pp. 1-26, doi:10.1007/s00445-012-0583-3, 2012.

Kylling, A., Buras, R., Eckhardt, S., Emde, C., Mayer, B., and Stohl, A.: Simulation of SEVIRI infrared channels: a case study from the Eyjafjallajökull April/May 2010 eruption, Atmos. Meas. Tech., 6, 649-660, doi:10.5194/amt-6-649-2013, 2013.

Kylling, A., Kahnert, M., Lindqvist, H., and Nousiainen, T.: Volcanic ash infrared signature: porous non-spherical ash particle shapes compared to homogeneous spherical ash particles, Atmos. Meas. Tech., 7, 919-929, doi:10.5194/amt-7-919-2014, 2014.

Lane, C. S., Andric, M., Cullen, V. L., and Blockley, S. P. E.: The occurrence of distal Icelandic and Italian tephra in the Lateglacial of Lake Bled, Slovenia, Quaternary Sci. Rev., 30, 1013-1018, doi:10.1016/j.quascirev.2011.02.014, 2011.

Lane, C. S., Blockley, S. P. E., Mangerud, J., Smith, V. C., Lohne, O. S., Tomlinson, E. L., Matthews, I. P., and Lotter, A. F.: Was the 12.1 ka Icelandic Vedde Ash one of a kind?, Quaternary Sci. Rev., 33, 87-99, doi:10.1016/j.quascirev.2011.11.011, 2012.

Lavigne, F., Degeai, J.-P., Komorowski, J.-C., Guillet, S., Robert, V., Lahitte, P., Oppenheimer, C., Stoffel, M., Vidal, C. M., Surono, Pratomo, I., Wassmer, P., Hajdas, I., Hadmoko, D. S., and de Belizal, E.: Source of the great A.D. 1257 mystery eruption unveiled, Samalas volcano, Rinjani Volcanic Complex, Indonesia, P. Natl. Acad. Sci. USA, 110, 16742-16747, doi:10.1073/pnas.1307520110, 2013.

Lawson, I. T., Swindles, G. T., Plunkett, G., and Greenberg, D.: The spatial distribution of Holocene cryptotephras in northwest Europe since $7 \mathrm{ka}$ : implications for understanding ash fall events from Icelandic eruptions, Quaternary Sci. Rev., 41, 5766, doi:10.1016/j.quascirev.2012.02.018, 2012. 
Leadbetter, S. J. and Hort, M. C.: Volcanic ash hazard climatology for an eruption of Hekla Volcano, Iceland, J. Volcanol. Geoth. Res., 199, 230-241, doi:10.1016/j.jvolgeores.2010.11.016, 2011.

Limpert, E., Stahel, W. A., and Abbt, M.: Log-normal distributions across the sciences: keys and clues, Bioscience, 51, 341-352, 2001.

Lowe, D. J.: Tephrochronology and its application: a review, Quat. Geochronol., 6, 107-153, doi:10.1016/j.quageo.2010.08.003, 2011.

Marenco, F. and Hogan, R. J.: Determining the contribution of volcanic ash and boundary layer aerosol in backscatter lidar returns: A three-component atmosphere approach, J. Geophys. Res.-Atmos., 116, D00U06, doi:10.1029/2010JD015415, 2011.

Maryon, R., Ryall, D., and Malcolm, A.: The NAME 4 dispersion model: Science documentation, Met Office turbulence and diffusion note, 262, 45, 1999.

Marzano, F. S., Lamantea, M., Montopoli, M., Herzog, M., Graf, H., and Cimini, D.: Microwave remote sensing of the 2011 Plinian eruption of the Grímsvötn Icelandic volcano, Remote Sens. Environ., 129, 168-184, doi:10.1016/j.rse.2012.11.005, 2013.

Matricardi, M.: The inclusion of aerosols and clouds in RTIASI, the ECMWF fast radiative transfer model for the Infrared Atmospheric Sounding Interferometer, "Technical Memorandum" 474, ECMWF, available at: http://old.ecmwf.int/publications/ library/do/references/list/14 (last access: 19 December 2014), 2005.

Matthews, N. E., Smith, V. C., Costa, A., Durant, A. J., Pyle, D. M., and Pearce, N. J. G.: Ultra-distal tephra deposits from super-eruptions: examples from Toba, Indonesia and Taupo Volcanic Zone, New Zealand, Quaternary Int., 258, 54-79, doi:10.1016/j.quaint.2011.07.010, 2012.

McCormick, B. T., Edmonds, M., Mather, T. A., Campion, R., Hayer, C. S. L., Thomas, H. E., and Carn, S. A.: Volcano monitoring applications of the Ozone Monitoring Instrument, Geological Society, London, Special Publications, 380, doi:10.1144/SP380.11, 2013.

Millington, S. C., Saunders, R., Francis, P., and Webster, H. N.: Simulated volcanic ash imagery: a method to compare NAME ash concentration forecasts with SEVIRI imagery for the Eyjafjallajökull eruption in 2010, J. Geophys. Res.-Atmos., 117, D00U1, doi:10.1029/2011JD016770, 2012.

Montopoli, M., Vulpiani, G., Cimini, D., Picciotti, E., and Marzano, F. S.: Interpretation of observed microwave signatures from ground dual polarization radar and space multi-frequency radiometer for the 2011 Grímsvötn volcanic eruption, Atmos. Meas. Tech., 7, 537-552, doi:10.5194/amt-7-537-2014, 2014.

Mortensen, A., Bigler, M., Grönvold, K., Steffensen, J., and Johnsen, S.: Volcanic ash layers from the last glacial termination in the NGRIP ice core, J. Quaternary Sci., 20, 209-219, doi:10.1002/jqs.908, 2005.

Newhall, C. G. and Self, S.: The Volcanic Explosivity Index (VEI) an estimate of explosive magnitude for historical volcanism, J. Geophys. Res., 87, 1231-1238, doi:10.1029/JC087iC02p01231, 1982.

Newton, A. J., Dugmore, A. J., and Gittings, B. M.: Tephrabase: tephrochronology and the development of a centralised European database, J. Quaternary Sci., 22, 737-743, doi:10.1002/jqs.1094, 2007.
Óladóttir, B. A., Larsen, G., and Sigmarsson, O.: Holocene volcanic activity at Grimsvotn, Bardarbunga and Kverkfjoll subglacial centres beneath Vatnajokull, Iceland, Bull. Volcanol., 73, 1187-1208, doi:10.1007/s00445-011-0461-4, 2011.

Palais, J. M., Germani, M. S., and Zielinski, G. A.: Interhemispheric transport of volcanic ash from a 1259 A.D. volcanic eruption to the Greenland and Antarctic Ice Sheets, Geophys. Res. Lett., 19, 801-804, doi:10.1029/92GL00240, 1992.

Pavolonis, M. J., Feltz, W. F., Heidinger, A. K., and Gallina, G. M.: A daytime complement to the reverse absorption technique for improved automated detection of volcanic ash, J. Atmos. Ocean. Tech., 23, 1422-1444, doi:10.1175/JTECH1926.1, 2006.

Pavolonis, M. J., Heidinger, A. K., and Sieglaff, J.: Automated retrievals of volcanic ash and dust cloud properties from upwelling infrared measurements, J. Geophys. Res.-Atmos., 118, 14361458, doi:10.1002/jgrd.50173, 2013.

Persson, C.: Tephrochronological investigation of peat deposits in Scandinavia and on the Faroe Islands, Sveriges reproduktions AB (distr.), 1971.

Petersen, G. N., Bjornsson, H., and Arason, P.: The impact of the atmosphere on the Eyjafjallajökull 2010 eruption plume, J. Geophys. Res., 117, D00U07, doi:10.1029/2011JD016762, 2012.

Pieri, D., Ma, C., Simpson, J. J., Hufford, G., Grindle, T., and Grove, C.: Analyses of in-situ airborne volcanic ash from the February 2000 eruption of Hekla Volcano, Iceland, Geophys Res. Lett., 29, 19.1-19.4, doi:10.1029/2001GL013688, 2002.

Pollack, J. B., Toon, O. B., and Khare, B. N.: Optical properties of some terrestrial rocks and glasses, Icarus, 19, 372-389, doi:10.1016/0019-1035(73)90115-2, 1973.

Prata, A. J.: Infrared radiative transfer calculations for volcanic ash clouds, Geophys. Res. Lett., 16, 1293-1296, doi:10.1029/GL016i011p01293, 1989.

Prata, A. J. and Grant, I. F.: Retrieval of microphysical and morphological properties of volcanic ash plumes from satellite data: application to Mt Ruapehu, New Zealand, Q. J. Roy. Meteor. Soc., 127, 2153-2179, doi:10.1002/qj.49712757615, 2001.

Prata, A. J. and Prata, A. T.: Eyjafjallajökull volcanic ash concentrations determined using Spin Enhanced Visible and Infrared Imager measurements, J. Geophys. Res., 117, D00U23, doi:10.1029/2011JD016800, 2012.

Prata, F., Bluth, G., Rose, B., Schneider, D., and Tupper, A.: Comments on "Failures in detecting volcanic ash from a satellite-based technique", Remote Sens. Environ., 78, 341-346, doi:10.1016/S0034-4257(01)00231-0, 2001.

Pyne-O’Donnell, S. D., Hughes, P. D., Froese, D. G., Jensen, B. J., Kuehn, S. C., Mallon, G., Amesbury, M. J., Charman, D. J., Daley, T. J., Loader, N. J., Mauquoy, D., Street-Perrott, F. A., and Woodman-Ralph, J.: High-precision ultra-distal Holocene tephrochronology in North America, Quaternary Sci. Rev., 52, 6-11, doi:10.1016/j.quascirev.2012.07.024, 2012.

Riley, C., Rose, W., and Bluth, G.: Quantitative shape measurements of distal volcanic ash, J. Geophys. Res.-Sol. Ea., 108, 2504, doi:10.1029/2001JB000818, 2003.

Rodgers, C. D.: Inverse Methods for Atmospheric Sounding: Theory and Practice, WORLD SCIENTIFIC, 2000.

Rose, W. and Durant, A.: Fine ash content of explosive eruptions, J. Volcanol. Geoth. Res., 186, 32-39, 2009.

Rose, W. I., Bluth, G. J. S., and Ernst, G. G. J.: Integrating retrievals of volcanic cloud characteristics from satellite remote 
sensors: a summary, Philos. T. Roy. Soc. A, 358, 1585-1606, doi:10.1098/rsta.2000.0605, 2000.

Rose, W. I., Bluth, G. J. S., Schneider, D. J., Ernst, G. G. J., Riley, C. M., Henderson, L. J., and McGimsey, R. G.: Observations of volcanic clouds in their first few days of atmospheric residence: the 1992 eruptions of Crater Peak, Mount Spurr Volcano, Alaska, J. Geol., 109, 677-694, doi:10.1086/323189, 2001.

Rose, W. I., Riley, C., and Dartevelle, S.: Sizes and shapes of 10-Ma distal fall pyroclasts in the Ogallala Group, Nebraska, J. Geol., 111, 115-124, doi:10.1086/344668, 2003.

Rust, A. C. and Cashman, K. V.: Permeability controls on expansion and size distributions of pyroclasts, J. Geophys. Res., 116, B11202, doi:10.1029/2011JB008494, 2011.

Saunders, R., Hocking, J., Rayer, P., Matricardi, M., Geer, A., Bormann, N., Brunel, P., Karbou, F., and Aires, F.: RTTOV-10 Science and Validation Report, available at: http://research.metoffice.gov.uk/research/interproj/nwpsaf/rtm/ (last access: 19 December 2014), 2012.

Scasso, R. A., Corbella, H., and Tiberi, P.: Sedimentological analysis of the tephra from the 12-15 August 1991 eruption of Hudson volcano, B. Volcanol., 56, 121-132, doi:10.1007/BF00304107, 1994.

Schumann, U., Weinzierl, B., Reitebuch, O., Schlager, H., Minikin, A., Forster, C., Baumann, R., Sailer, T., Graf, K., Mannstein, H., Voigt, C., Rahm, S., Simmet, R., Scheibe, M., Lichtenstern, M., Stock, P., Rüba, H., Schäuble, D., Tafferner, A., Rautenhaus, M., Gerz, T., Ziereis, H., Krautstrunk, M., Mallaun, C., Gayet, J.F., Lieke, K., Kandler, K., Ebert, M., Weinbruch, S., Stohl, A., Gasteiger, J., Groß, S., Freudenthaler, V., Wiegner, M., Ansmann, A., Tesche, M., Olafsson, H., and Sturm, K.: Airborne observations of the Eyjafjalla volcano ash cloud over Europe during air space closure in April and May 2010, Atmos. Chem. Phys., 11, 2245-2279, doi:10.5194/acp-11-2245-2011, 2011.

Seinfeld, J. H. and Pandis, S. N.: Atmospheric Chemistry and Physics: from Air Pollution to Climate Change, WileyInterscience, Hoboken, NJ, 2nd edn., 2006.

Stevenson, J. A., Loughlin, S., Rae, C., Thordarson, T., Milodowski, A. E., Gilbert, J. S., Harangi, S., Lukács, R., Højgaard, B., Árting, U., Pyne-O'Donnell, S., MacLeod, A., Whitney, B., and Cassidy, M.: Distal deposition of tephra from the Eyjafjallajökull 2010 summit eruption, J. Geophys. Res., 117, B00C10, doi:10.1029/2011JB008904, 2012.

Stevenson, J. A., Loughlin, S. C., Font, A., Fuller, G. W., MacLeod, A., Oliver, I. W., Jackson, B., Horwell, C. J., Thordarson, T., and Dawson, I.: UK monitoring and deposition of tephra from the May 2011 eruption of Grímsvötn, Iceland, J. Appl. Volcanol., 2, 3, doi:10.1186/2191-5040-2-3, 2013.

Stohl, A., Prata, A. J., Eckhardt, S., Clarisse, L., Durant, A., Henne, S., Kristiansen, N. I., Minikin, A., Schumann, U., Seibert, P., Stebel, K., Thomas, H. E., Thorsteinsson, T., Tørseth, K., and Weinzierl, B.: Determination of time- and height-resolved volcanic ash emissions and their use for quantitative ash dispersion modeling: the 2010 Eyjafjallajökull eruption, Atmos. Chem. Phys., 11, 4333-4351, doi:10.5194/acp-11-4333-2011, 2011.
Swindles, G. T., De Vleeschouwer, F., and Plunkett, G.: Dating peat profiles using tephra: stratigraphy, geochemistry and chronology, Mires and Peats, 7, 1-9, 2010.

Swindles, G. T., Lawson, I. T., Savov, I. P., Connor, C. B., and Plunkett, G.: A $7000 \mathrm{yr}$ perspective on volcanic ash clouds affecting northern Europe, Geology, 39, 887-890, doi:10.1130/G32146.1, 2011.

Tesche, M., Glantz, P., Johansson, C., Norman, M., Hiebsch, A., Ansmann, A., Althausen, D., Engelmann, R., and Seifert, P.: Volcanic ash over Scandinavia originating from the Grimsvotn eruptions in May 2011, J. Geophys. Res.-Atmos., 117, D09201, doi:10.1029/2011JD017090, 2012.

Thomas, G. E., Poulsen, C. A., Sayer, A. M., Marsh, S. H., Dean, S. M., Carboni, E., Siddans, R., Grainger, R. G., and Lawrence, B. N.: The GRAPE aerosol retrieval algorithm, Atmos. Meas. Tech., 2, 679-701, doi:10.5194/amt-2-679-2009, 2009.

Thorarinsson, S.: Greetings from Iceland: ash-falls and volcanic aerosols in Scandinavia, Geogr. Ann. A, 63, 109-118, 1981.

Turnbull, K., Johnson, B., Marenco, F., Haywood, J., Minikin, A., Weinzierl, B., Schlager, H., Schumann, U., Leadbetter, S., and Woolley, A.: A case study of observations of volcanic ash from the Eyjafjallajökull eruption: 1. In situ airborne observations, J. Geophys. Res.-Atmos., 117, D00U12, doi:10.1029/2011JD016688, 2012.

Wastegård, S., Wohlfarth, B., Subetto, D. A., and Sapelko, T. V.: Extending the known distribution of the Younger Dryas Vedde Ash into northwestern Russia, J. Quaternary Sci., 15, 581-586, doi:10.1002/1099-1417(200009)15:6<581::AIDJQS558>3.0.CO;2-3, 2000.

Webster, H. N., Thomson, D. J., Johnson, B. T., Heard, I. P. C., Turnbull, K., Marenco, F., Kristiansen, N. I., Dorsey, J., Minikin, A., Weinzierl, B., Schumann, U., Sparks, R. S. J., Loughlin, S. C., Hort, M. C., Leadbetter, S. J., Devenish, B. J., Manning, A. J., Witham, C. S., Haywood, J. M., and Golding, B. W.: Operational prediction of ash concentrations in the distal volcanic cloud from the 2010 Eyjafjallajökull eruption, J. Geophys. Res.Atmos., 117, D00U08, doi:10.1029/2011JD016790, 2012.

Wen, S. and Rose, W. I.: Retrieval of sizes and total masses of particles in volcanic clouds using AVHRR bands 4 and 5, J. Geophys. Res., 99, 5421-5431, doi:10.1029/93JD03340, 1994.

White, J. and Houghton, B.: Primary volcaniclastic rocks, Geology, 34, 677-680, doi:10.1130/G22346.1, 2006.

Wohletz, K., Sheridan, M., and Brown, W.: Particle size distributions and the sequential fragmentation/transport theory applied to volcanic ash, J. Geophys. Res., 94, 15703-15721, 1989.

Zdanowicz, C. M., Zielinski, G. A., and Germani, M. S.: Mount Mazama eruption: calendrical age verified and atmospheric impact assessed, Geology, 27, 621-624, doi: 10.1130/00917613(1999)027<0621:MMECAV>2.3.CO;2, 1999.

Zielinski, G. A., Mayewski, P. A., Meeker, L. D., Grönvold, K., Germani, M. S., Whitlow, S., Twickler, M. S., and Taylor, K.: Volcanic aerosol records and tephrochronology of the Summit, Greenland, ice cores, J. Geophys. Res., 102, 26625-26640, doi:10.1029/96JC03547, 1997. 